\title{
Publics Worldwide
}

Unfavorable Toward

Putin, Russia

Butfew see Russian power and influence as a major threat

BY Margaret Vice

FOR MEDIA OR OTHER INQUIRIES:

Margaret Vice, Senior Researcher

Rhonda Stewart, Senior Communications Manager

202.419 .4372

www.pewresearch.org 


\section{About Pew Research Center}

Pew Research Center is a nonpartisan fact tank that informs the public about the issues, attitudes and trends shaping America and the world. It does not take policy positions. The Center conducts public opinion polling, demographic research, content analysis and other data-driven social science research. It studies U.S. politics and policy; journalism and media; internet, science and technology; religion and public life; Hispanic trends; global attitudes and trends; and U.S. social and demographic trends. All of the center's reports are available at www.pewresearch.org. Pew Research Center is a subsidiary of The Pew Charitable Trusts, its primary funder.

(c) Pew Research Center 2017 


\section{Publics Worldwide Unfavorable Toward Putin, Russia}

\section{Butfew see Russian power and influence as a major threat}

Around the world, few people trust Russian President Vladimir Putin to do the right thing when it comes to international affairs. A global median of roughly one-in-four (26\%) say they have confidence in the Russian leader. Doubts about Putin's handling of foreign policy, however, do not necessarily coincide with perceptions of Russia as a security risk. Across 37 countries, a median of $31 \%$ describe Russia's power and influence as a major threat to their country - identical to the median percentage who say the same about China, and similar to the median share (35\%) that sees America's power and influence as a large threat.

On balance, Russia's international image is more negative than positive. Critical opinions of Russia are particularly widespread in the United States and Europe, while views are more mixed in the Asia-Pacific, the Middle East, sub-Saharan Africa and Latin America. In only three countries surveyed do majorities express a favorable opinion of Russia: Vietnam (83\%), Greece (64\%) and the Philippines (55\%).

\section{Little confidence in Putin, low opinions of Russia}

Regional medians saying ...

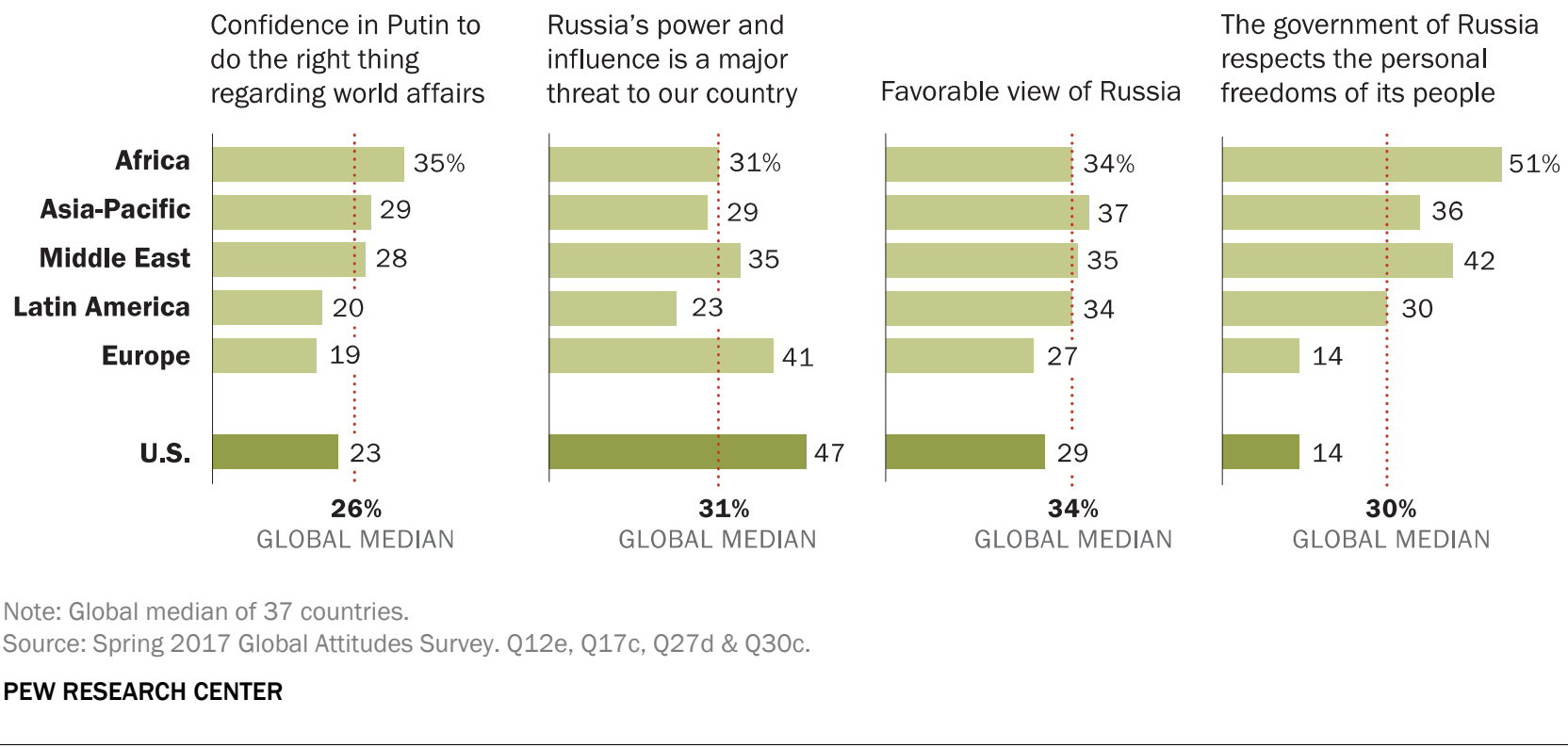


Many people doubt the Russian government's commitment to civil liberties. Globally, a median of $30 \%$ say Russia respects the rights of its citizens, compared with $46 \%$ who disagree and $17 \%$ who do not offer an opinion. Skepticism about the protection of personal freedoms in Russia is widespread in the U.S. and Europe. Views are mixed across the Asia-Pacific, the Middle East and Latin America, while publics in sub-Saharan Africa are more convinced than not that the Russian government safeguards individual liberties at home.

These are among the major findings from a new Pew Research Center survey conducted among 40,951 respondents in 37 countries outside of Russia from Feb. 16 to May 8, 2017. (For views from within Russia, see “Russians Remain Confident in Putin’s Global Leadership.")

Europeans are particularly harsh in their assessment of Putin, with a median in Europe of 78\% expressing a lack of confidence in the leader. In the U.S. and Canada, few are confident in Putin's global leadership, with more than three times as many people disliking Putin as liking him.

In a handful of nations (Vietnam, the Philippines, Tanzania and Greece), half or more are positive on Putin's international performance. In other nations, many do not express any view of him: Roughly one-third or more in India, Indonesia, Ghana, Senegal, South Africa and Argentina do not share an opinion on the Russian leader.

Though Putin and Russia receive low ratings across much of the world, few see Russian power and influence as a major threat to their nation. Russia is seen as far less threatening than other issues such as the Islamic State militant group (ISIS) and climate change in every nation surveyed except for Poland and J ordan. A global median of 31\% say that Russian power poses a major threat to their nation, compared with $62 \%$ for ISIS, $61 \%$ for climate change and $51 \%$ for cyberattacks from other countries and for the condition of the global economy. In fact, among the eight threats tested, Russia's power and influence is tied with that of China for last place (median of 31\%). (For views on global threats, see “Globally, People Point to ISIS and Climate Change as Leading Security Threats.")

Generally, the Russian government is not seen as respecting the personal freedoms of its people. Across the 37 nations surveyed, a median of only $30 \%$ believe that Russia adheres to this tenet of democracy; that is lower than those who believe the same of France (60\%, excluding France's figures) and the U.S. (54\%, excluding U.S. figures) but higher than for China (25\%).

Both Americans (80\%) and Canadians (73\%) widely feel that Putin's government does not respect personal freedoms. Similarly high shares feel this way in most European countries surveyed. 
In the Middle East and the Asia-Pacific, views vary among the countries polled. Majorities in Tunisia, Lebanon, Vietnam and the Philippines think Russia respects civil liberties, while publics elsewhere in these regions are split on the issue.

\section{Few have confidence in Putin on the international stage}

In few countries surveyed do people exhibit confidence in Putin to do the right thing regarding world affairs. Globally, a median of $60 \%$ say they lack confidence in Putin's global leadership.

Europe is the region least confident in Putin, with a median of $78 \%$ expressing a lack of confidence in the Russian president. Eight-inten or more in Poland (89\%), Spain (88\%), the Netherlands (87\%), Sweden (87\%) and France (80\%) lack trust in Putin.

About half or more across the countries surveyed in Latin America also express doubts about Putin's handling of foreign affairs. The same is true in the Middle East, with the exception of Tunisia, where views are more evenly divided (32\% confident vs. 39\% not confident).

Views of Putin are mixed in Africa, with sizable percentages not offering an opinion. Only in Tanzania do as many as half (51\%) express confidence in the Russian leader's international policies.

\section{Most have little confidence in Putin}

How much confidence do you have in Russian President Putin to do the right thing regarding world affairs?

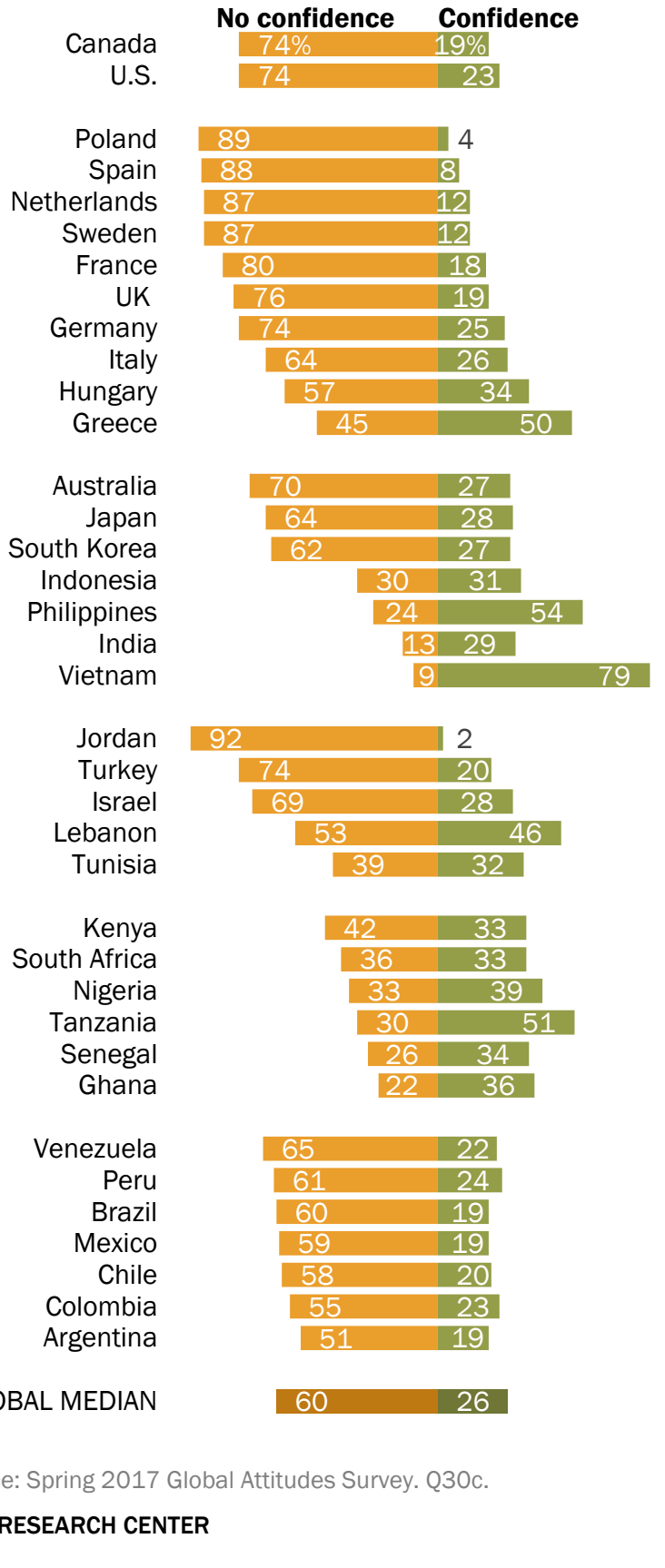

Putin also has the trust of half or more Vietnamese (79\%), Filipinos (54\%) and Greeks (50\%). 
Although confidence in Putin's handling of foreign affairs is generally low, in many countries he is more trusted than American President Donald Trump. Confidence in Putin most dramatically outpaces that in Trump in Greece and Lebanon (both +31 percentage points) and Vietnam ( +21 points). On the other hand, confidence in Putin lags significantly behind confidence in Trump in Israel (-28 points), Nigeria and Poland (both -19 points) and Kenya (-18 points).

In terms of bilateral views, Americans are less confident in Putin than Russians are in Trump: Only 23\% of the U.S. public has confidence in Putin on the world stage, whereas 53\% of Russians have confidence in Trump. (Russia was surveyed during the same period as the other 37 countries, though its results are excluded elsewhere in this report.)

In a number of countries, gender matters when it comes to confidence in Putin. In 10 of the 37 countries polled, men express more confidence in Putin than do women.

Political ideology is also linked to views of Putin. In 11 of the 21 countries in which respondents were asked about ideology, those who place themselves on the right of the political spectrum are more confident in Putin. This is especially the case in Italy, where $39 \%$ of those on the right look favorably toward Putin compared with $24 \%$ on the left; in Greece (62\% vs. $47 \%$ ); and in Australia (33\% vs. 19\%).

In Venezuela, the trend is decidedly the opposite, with those on the left of the political spectrum being 28 points more likely to support Putin on the international stage. There is an 11-point gap in the same direction in Israel.

In the U.S., there is a partisan divide in views of Putin. Today, only $13 \%$ of Democrats express confidence in Putin, compared with about a third (34\%) of Republicans. In 2015, there was almost no partisan gap: 20\% of self-identified Democrats were confident in the Russian leader, compared with $17 \%$ of Republicans.

\section{Confidence in Putin vs. Trump}

Confidence in __ to do the right thing regarding world affairs

\begin{tabular}{lccc} 
& & & \\
& Trump & Putin & Diff \\
Greece & $\%$ & $\%$ & \\
Lebanon & 19 & 50 & +31 \\
Vietnam & 15 & 46 & +31 \\
Germany & 58 & 79 & +21 \\
Tunisia & 11 & 25 & +14 \\
Mexico & 5 & 32 & +14 \\
South Korea & 17 & 27 & +10 \\
Turkey & 11 & 20 & +9 \\
Indonesia & 23 & 31 & +8 \\
Senegal & 26 & 34 & +8 \\
Chile & 12 & 20 & +8 \\
Colombia & 15 & 23 & +8 \\
Peru & 17 & 24 & +7 \\
Argentina & 13 & 19 & +6 \\
Hungary & 29 & 34 & +5 \\
Brazil & 14 & 19 & +5 \\
France & 14 & 18 & +4 \\
Japan & 24 & 28 & +4 \\
Sweden & 10 & 12 & +2 \\
Venezuela & 20 & 22 & +2 \\
Italy & 25 & 26 & +1 \\
Spain & 7 & 8 & +1 \\
Tanzania & 51 & 51 & 0 \\
\hline Australia & 29 & 27 & -2 \\
Canada & 22 & 19 & -3 \\
UK & 22 & 19 & -3 \\
Netherlands & 17 & 12 & -5 \\
South Africa & 39 & 33 & -6 \\
Jordan & 9 & 2 & -7 \\
India & 40 & 29 & -11 \\
Ghana & 49 & 36 & -13 \\
Philippines & 69 & 54 & -15 \\
Kenya & 51 & 33 & -18 \\
Poland & 23 & 4 & -19 \\
Nigeria & 58 & 39 & -19 \\
Israel & 56 & 28 & -28 \\
\hline & & &
\end{tabular}

Source: Spring 2017 Global Attitudes Survey. Q30a, C.

PEW RESEARCH CENTER 


\section{Russia not seen as particularly threatening in most countries}

Compared with other global threats such as ISIS or climate change, most people around the globe express relatively muted concerns about Russia's power and influence. Of the 37 nations polled, only in Poland and J ordan does Russia rank among the top three perceived threats to national security.

In the U.S., $47 \%$ view Russian power with great concern, though far more Americans view ISIS, cyberattacks and climate change with alarm. In Canada, only 30\% view Russia's power as a major threat, putting it among Canadians' lowest-level concerns of the eight included in the survey.

Outside of Poland, most European publics express substantial but not overwhelming concern about their neighbor to the east. Greeks (24\% major threat) and Hungarians (28\%) are the least worried about Russia's power and influence.

In the Middle East, only in Turkey do more than half (54\%) see Russia as a threat to their country. Elsewhere in the region, concern is less widespread, with Israelis (27\%) least worried. Across sub-Saharan Africa and Latin America, a third or fewer see Russia as very threatening. The exception is Kenya, where roughly four-in-ten (39\%) express great concern about Russia's power and influence.

\section{Most do not see Russia as a major threat to their country}

Russia's power and influence is a major threat to our country
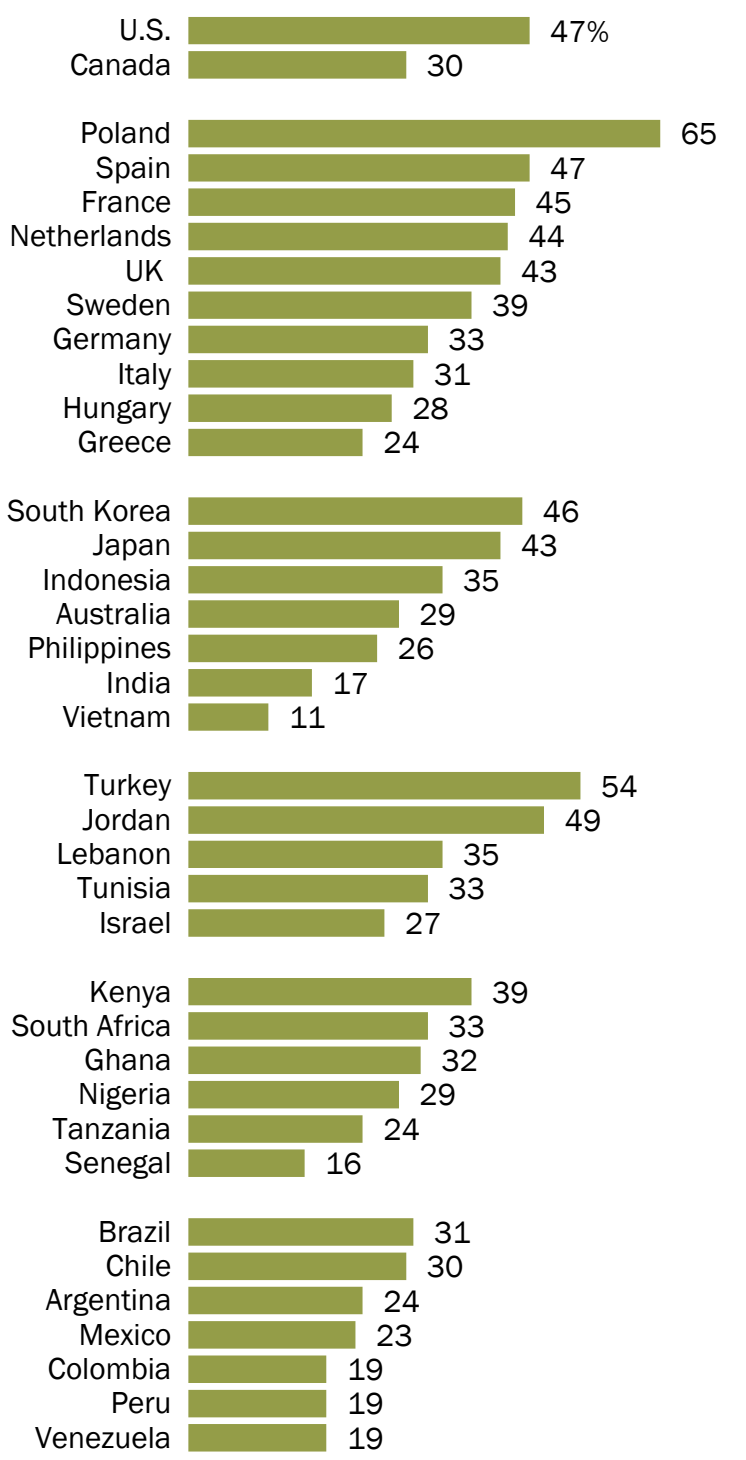

GLOBAL MEDIAN

PEW RESEARCH CENTER 
In some instances, concerns about Russia vary by education level. ${ }^{1}$ In the U.S., for example, those with more education are slightly more likely to view Russia as a major threat than people with less education (51\% vs. 44\%). There is a wider education gap in the same direction in the Philippines (those with more education are 12 percentage points more likely to see Russia as a threat).

Especially in the United States, political leaning plays a role in views of Russia. Roughly six-in-ten Democrats (61\%) view Russia as a major risk to national security, whereas only $36 \%$ of Republicans feel the same.

\section{In U.S., Democrats feel more threatened by Russian power}

Russia's power and influence is a major threat to our country

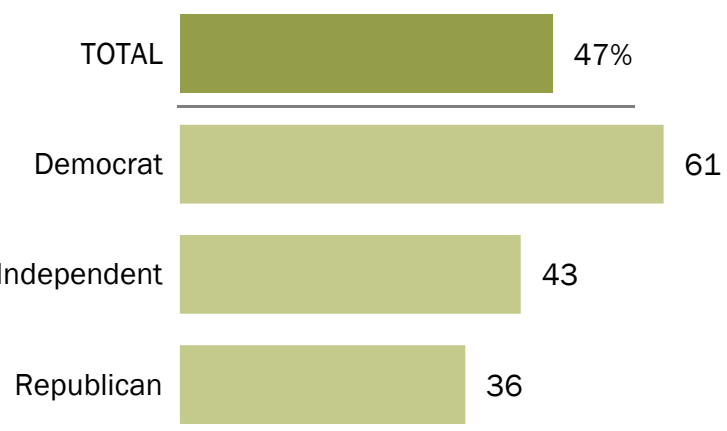

Source: Spring 2017 Global Attitudes Survey. Q17C.

PEW RESEARCH CENTER

\footnotetext{
1 For the purpose of comparing education groups across countries, we standardize education levels based on the UN's International Standard Classification of Education (ISCED). The lower education category is below secondary education and the higher category is secondary or above in Argentina, Brazil, Chile, Colombia, Ghana, India, Indonesia, Jordan, Kenya, Lebanon, Mexico, Nigeria, Peru, Philippines, Senegal, South Africa, Tanzania, Tunisia, Turkey, Venezuela and Vietnam. The lower education category is secondary education or below and the higher category is postsecondary or above in Australia, Canada, France, Germany, Greece, Hungary, Israel, Italy, Japan, Netherlands, Poland, Russia, South Korea, Spain, Sweden, UK and U.S.
} 


\section{Russia viewed unfavorably in many countries}

Opinions of Russia are more unfavorable than favorable in 19 of the 37 nations outside Russia that were surveyed. A median of just $34 \%$ view Russia in a positive light overall, while $40 \%$ view the country negatively. This reflects a slight improvement of Russia's global image: In 2015, a global median of $51 \%$ viewed Russia negatively.

Regionally, Russia's reputation is least favorable in Europe and North America. A full $63 \%$ of Americans and 59\% of Canadians hold negative views of Russia. In Europe, a median of $61 \%$ feel the same, with anti-Russian sentiment particularly intense in the Netherlands (82\%) and Sweden (78\%).

In the Middle East, majorities in Jordan (93\%), Turkey (62\%) and Israel (61\%) hold negative views of Russia. Anti-Russian sentiment in Jordan has nearly doubled over the past decade - intensifying even before Russia's involvement in the Syrian conflict.

\section{Opinion of Russia unfavorable in much of the world}

Views of Russia

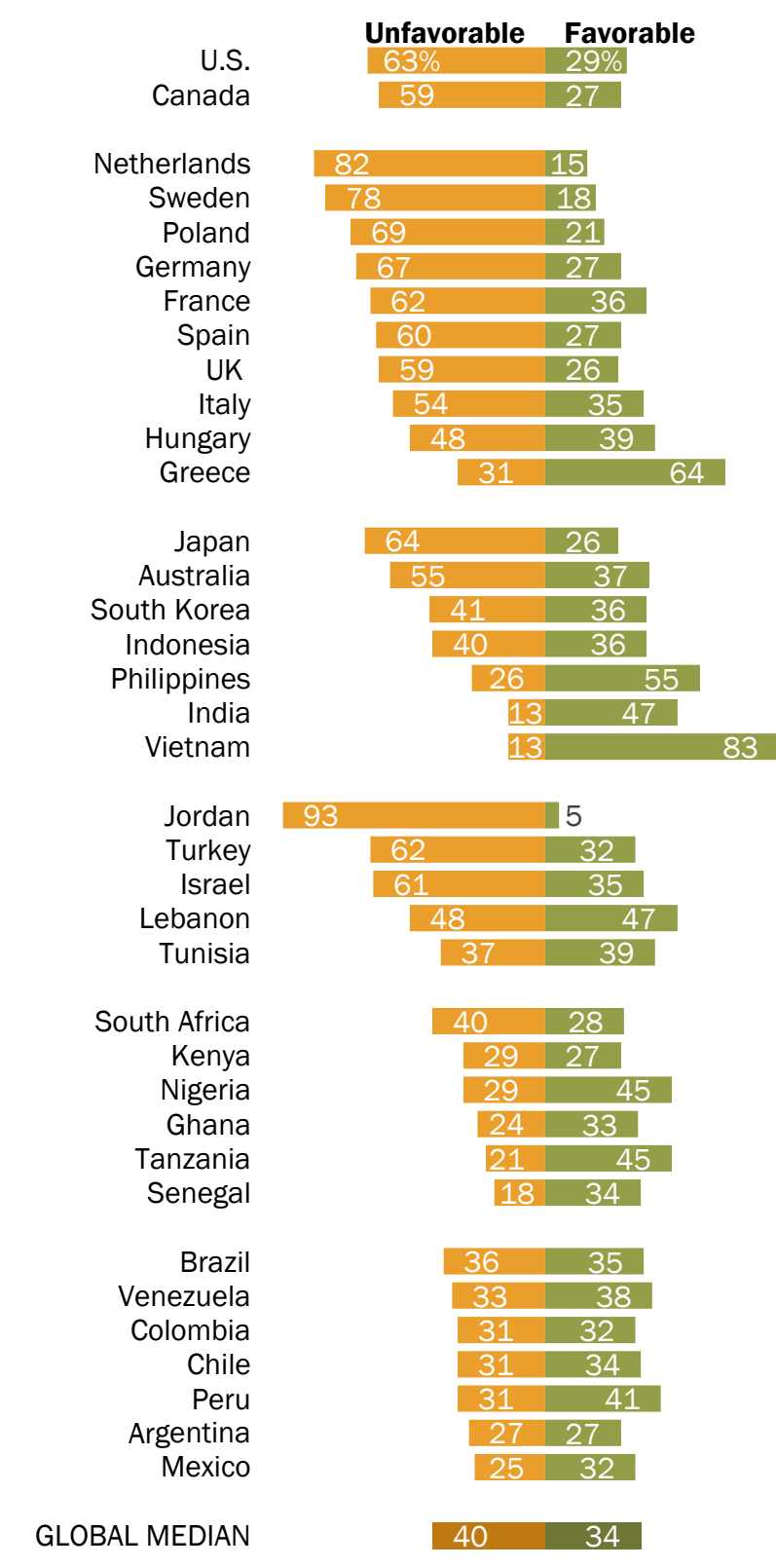

Source: Spring 2017 Global Attitudes Survey. Q12e.

PEW RESEARCH CENTER 
Opinion is split in both Tunisia and Lebanon. Within Lebanon, views vary by religious sect: $83 \%$ of Shiites view Russia favorably, while only $21 \%$ of Sunnis and $38 \%$ of Christians feel the same.

Views of Russia are mixed in Latin America and subSaharan Africa, with many people undecided or not offering an opinion. Across the two regions, favorable views of Russia are most common in Nigeria (45\% favorable), Tanzania (45\%) and Peru (41\%), while negative opinion is most pronounced in South Africa

\section{Jordanians increasingly negative on Russia}

Views of Russia

$100 \%$

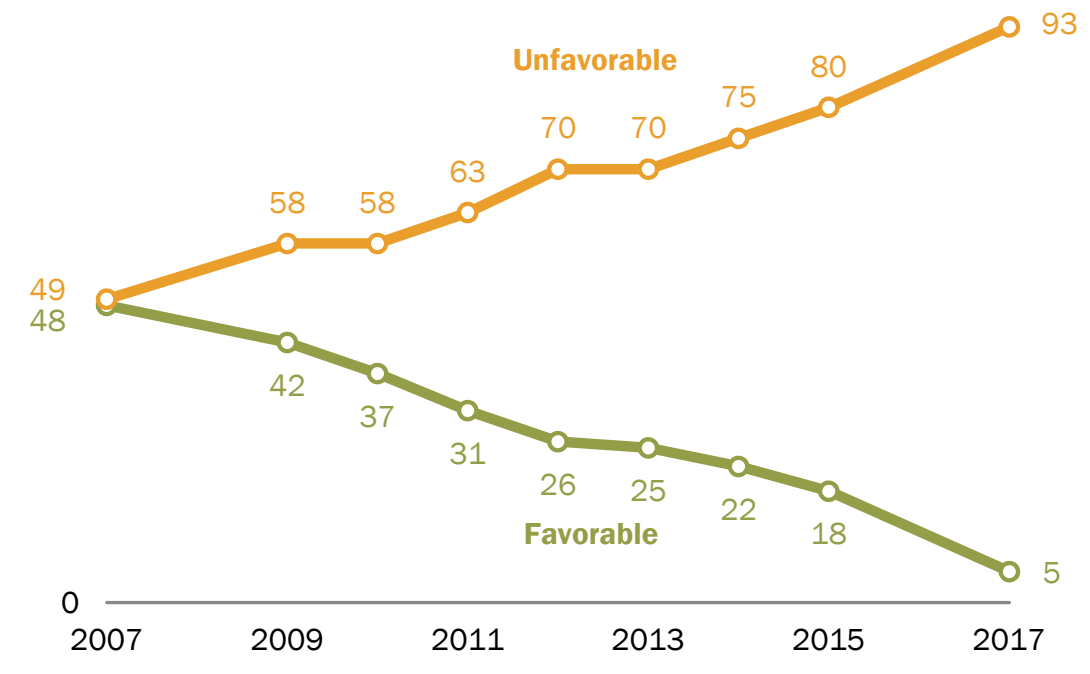

Source: Spring 2017 Global Attitudes Survey. Q12e.

PEW RESEARCH CENTER (40\% unfavorable) and Brazil (36\%).

Across all countries surveyed, Russia's image is strongest in Vietnam, Greece and the Philippines; in all three countries, more than half the public holds a favorable view of Russia. In Greece, Russia's favorability rating has stayed steady, hovering just above six-in-ten since Pew Research Center began measuring it in 2012; it currently stands at 64\%.

In both the Philippines and Vietnam, sentiment toward Russia has improved over time. In Vietnam, 83\% currently hold favorable views of Russia, an 8-point jump since 2015. And Filipinos, led by a president who appears to be shifting alliances away from the U.S. and toward Russia, are now significantly more favorable toward Russia (55\%) than they were four years ago (35\% in 2013). 
American and Russian views of one another have become less harsh since turning intensely negative in the wake of Russia's annexation of Crimea and the imposition of Western sanctions on Russia. Today, roughly fourin-ten Russians (41\%) feel favorably toward the United States, compared with just $15 \%$ in 2015 . Views in the U.S. toward Russia have eased less: 22\% of Americans felt favorably toward Russia in 2015, compared with $29 \%$ today.

\section{Russian and American opinions of each other improve} $80 \%$

$$
\text { U.S. favorability in Russia }
$$
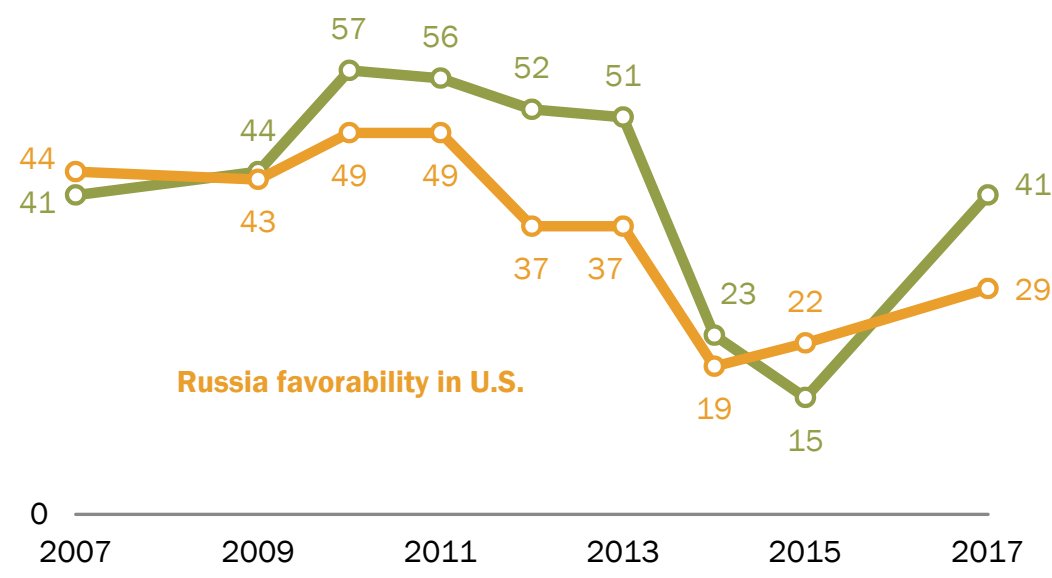

Source: Spring 2017 Global Attitudes Survey. Q12a, e.

PEW RESEARCH CENTER

In the U.S., partisan differences in attitudes toward Russia have emerged. In 2015, Democrats (71\% unfavorable) and Republicans (73\% unfavorable) held comparably negative views of Russia. In the past two years, Republican views have become significantly more positive, while Democratic views are little changed. Today, only $16 \%$ of Democrats have a favorable view of Russia, compared with $41 \%$ of Republicans.

(For more, see the J une 26 report, “U.S. Image Suffers as Publics Around World Question Trump's Leadership..") 
Across many nations, older people are significantly less likely to view Russia favorably than their younger counterparts - and in no nation are younger people significantly more critical of Russia than the older generation. In 12 nations, those ages 50 and older hold much more negative views of Russia than those 18 to 29. The generation gap is most notable in J apan and Brazil (both reveal a 37-point generational gap on favorability of Russia), Australia (24 points) and South Korea (22 points). In 11 other nations, anywhere from $40 \%$ to nearly $60 \%$ of those 50 and older offer no opinion on Russia.

Men also tend to favor Russia more than women: In seven nations, the share of men who feel warmly about Russia is anywhere from 7 to 17 points higher than the share of women who feel the same way. This gender gap is most pronounced in France (17-point gap) and Germany (14 points).

\section{Russia is more favored among young}

Favorable view of Russia

\begin{tabular}{lc|cccc} 
& $\begin{array}{c}\text { TOTAL } \\
\%\end{array}$ & $\mathbf{1 8 - 2 9}$ & $\mathbf{3 0 - 4 9}$ & $\mathbf{5 0 +}$ & $\begin{array}{c}\text { Young- } \\
\text { old gap }\end{array}$ \\
& $\%$ & $\%$ & $\%$ & \\
Japan & 26 & 53 & 33 & 16 & $\mathbf{+ 3 7}$ \\
Brazil & 35 & 57 & 34 & 20 & $\mathbf{+ 3 7}$ \\
Australia & 37 & 54 & 38 & 30 & $\mathbf{+ 2 4}$ \\
South Korea & 36 & 51 & 37 & 29 & $\mathbf{+ 2 2}$ \\
UK & 26 & 42 & 25 & 21 & $\mathbf{+ 2 1}$ \\
Germany & 27 & 39 & 29 & 22 & $\mathbf{+ 1 7}$ \\
Spain & 27 & 38 & 28 & 21 & $\mathbf{+ 1 7}$ \\
U.S. & 29 & 40 & 27 & 25 & $\mathbf{+ 1 5}$ \\
Vietnam & 83 & 89 & 82 & 74 & $\mathbf{+ 1 5}$ \\
Canada & 27 & 35 & 31 & 21 & $\mathbf{+ 1 4}$ \\
Netherlands & 15 & 25 & 13 & 12 & $\mathbf{+ 1 3}$ \\
Turkey & 32 & 37 & 31 & 26 & $\mathbf{+ 1 1}$ \\
\hline
\end{tabular}

Source: Spring 2017 Global Attitudes Survey. Q12e.

PEW RESEARCH CENTER

The relationship between education level and views of Russia varies by region. In France, the U.S. and Sweden, those with lower levels of education are significantly more likely to feel favorably toward Russia. However, in Tunisia and Turkey, those with higher levels of education are more likely to feel favorably toward Russia. 


\section{Many question Russia's protection of personal freedoms}

Globally, a median of 30\% think the Russian government respects the personal freedom of its people. In North America, people in both the U.S. (80\%) and Canada (73\%) feel strongly that the Russian government does not respect civil liberties. In Europe, roughly eight-in-ten feel the same way in Sweden, the Netherlands, France, Poland and Germany. Greeks are the most likely to say Russia protects individual freedoms (43\%).

Contrasting views on Russia's respect for personal freedoms are found in both Asia and the Middle East. Majorities in Australia (75\%), Japan (61\%) and South Korea (56\%) doubt the Russian government on this score, compared with most Vietnamese (85\%) and Filipinos (59\%) who think Russia is protecting civil liberties at home.

In the Middle East, Israel is the only country surveyed where a clear majority does not believe the Putin administration is protecting the rights of Russian citizens. In contrast, majorities in Tunisia (80\%) and Lebanon (70\%) give Russia favorable marks in this regard.

In sub-Saharan Africa, positive assessments of Russia's record on civil liberties consistently outweigh negative views, especially in Nigeria and Senegal, where a $65 \%$ majority in each country says Putin's government protects individual freedoms.

Across Latin America, publics tend to be

\section{Russia widely seen as not respecting personal freedoms}

Do you think the government of Russia respects the personal freedoms of its people?

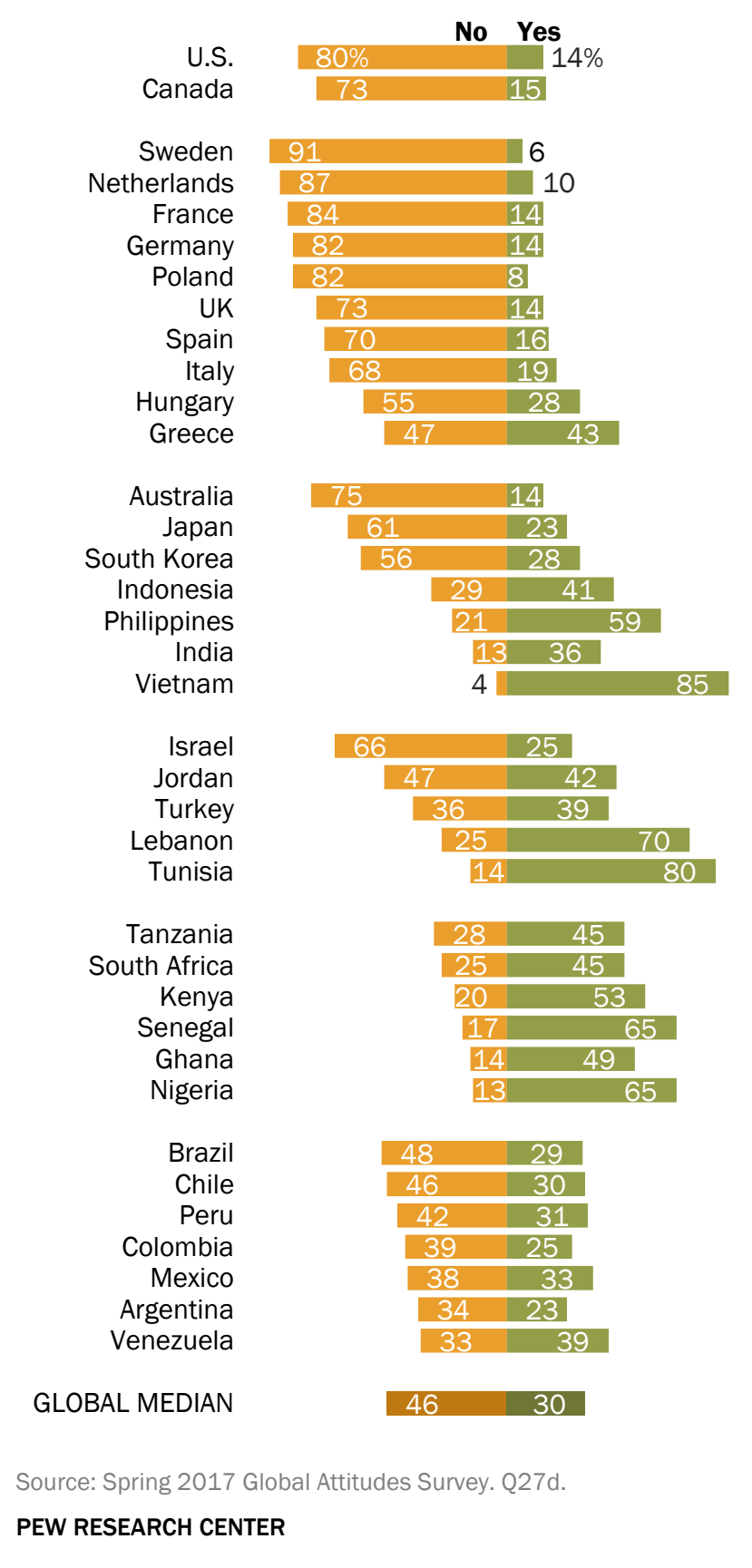


divided on the issue. In Venezuela and Mexico, there is a 5- to 6-point difference in the share that thinks Russia respects freedoms and the share that thinks it doesn't. In Argentina and Peru, the share that does not believe personal freedoms are respected in Russia is 11 points higher than the share that thinks they are. And in Brazil, Chile and Colombia, views are slightly stronger that Russia does not respect freedoms.

Across many countries surveyed, young people are more likely to believe that Russia respects the personal freedoms of its people. And nowhere is the oldest age group more likely to believe that Russia respects its people's freedoms. In J apan, South Korea, Germany, the Netherlands, Australia, Chile and Spain, the gap between the youngest and oldest groups is 14 percentage points or more. 


\section{Acknowledgments}

This report is a collaborative effort based on the input and analysis of the following individuals.

Margaret Vice, Senior Researcher

James Bell, Vice President, Global Strategy

Caldwell Bishop, Research Associate

Hanyu Chwe, Research Assistant

Stefan Cornibert, Communications Manager

Danielle Cuddington, Research Analyst

Claudia Deane, Vice President, Research

Janell Fetterolf, Research Associate

Simona Griffith, Intern

Hamza Jaleel, Intern

Courtney Johnson, Research Associate

Michael Keegan, Information Graphics Designer

David Kent, Copy Editor

Dorothy Manevich, Research Analyst

Patrick Moynihan, Associate Director, International Research Methods

Jacob Poushter, Senior Researcher

Audrey Powers, Administrative Manager

Ariana Rodriguez-Gitler, Digital Producer

Steve Schwarzer, Senior Research Methodologist

Laura Silver, Senior Researcher

Katie Simmons, Associate Director, Research

Rhonda Stewart, Senior Communications Manager

Bruce Stokes, Director, Global Economic Attitudes

Kyle Taylor, Research Assistant

Richard Wike, Director, Global Attitudes Research

Benjamin Wormald, Web Developer 


\section{Methodology}

About the Pew Research Center's Spring 2017 Global Attitudes Survey

Results for the survey are based on telephone and face-to-face interviews conducted under the direction of D3 Systems, Inc., ORB International, Princeton Survey Research Associates International, Kantar Public UK and Voices! Research \& Consultancy. The results are based on national samples, unless otherwise noted. More details about our international survey methodology and country-specific sample designs are available here.

Detailed information on survey methods for this report

General information on international survey research 


\title{
Topline Questionnaire
}

\author{
Pew Research Center \\ Spring 2017 Survey \\ August 16, 2017 Release
}

Methodological notes:

- Survey results are based on national samples. For further details on sample designs, see Methodology section and our international survey methods database.

- Due to rounding, percentages may not total 100\%. The topline "total" columns show 100\%, because they are based on unrounded numbers.

- $\quad$ Since 2007, the Pew Research Center has used an automated process to generate toplines for its Global Attitudes surveys. As a result, numbers may differ slightly from those published prior to 2007.

- Throughout this report, trends from India in 2013 refer to a survey conducted between December 7, 2013, and J anuary 12, 2014 (Winter 2013-2014).

- For some countries, trends for certain years are omitted due to differences in sample design or population coverage. Omitted trends often reflect less representative samples than more recent surveys in the same countries. Trends that are omitted include:

- Vietnam prior to 2014

- $\quad$ India prior to Winter 2013-2014

- Senegal prior to 2013

- Venezuela prior to 2013

- $\quad$ Brazil prior to 2010

- $\quad$ Nigeria prior to 2010

- $\quad$ South Africa in 2007

- Indonesia prior to 2005

- Poland in March 2003

- $\quad$ Not all questions included in the Spring 2017 survey are presented in this topline. Omitted questions have either been previously released or will be released in future reports. 
PEW RESEARCH CENTER

\begin{tabular}{|c|c|c|c|c|c|c|c|}
\hline & & \multicolumn{6}{|c|}{ Q12e. Please tell me if you have a very favorable, somewhat favorable, somewhat unfavorable or very unfavorable opinion of } \\
\hline & & Very favorable & $\begin{array}{c}\text { Somewhat } \\
\text { favorable }\end{array}$ & $\begin{array}{l}\text { Somewhat } \\
\text { unfavorable }\end{array}$ & Very unfavorable & DK/ Refused & Total \\
\hline \multirow[t]{9}{*}{ United States } & Spring, 2017 & 3 & 26 & 35 & 28 & 9 & 100 \\
\hline & Spring, 2015 & 3 & 19 & 40 & 27 & 12 & 100 \\
\hline & Spring, 2014 & 3 & 16 & 34 & 38 & 9 & 100 \\
\hline & Spring, 2013 & 4 & 33 & 29 & 14 & 20 & 100 \\
\hline & Spring, 2012 & 5 & 32 & 27 & 13 & 24 & 100 \\
\hline & Spring, 2011 & 8 & 41 & 22 & 10 & 19 & 100 \\
\hline & Spring, 2010 & 7 & 42 & 24 & 8 & 19 & 100 \\
\hline & Spring, 2009 & 7 & 36 & 27 & 12 & 18 & 100 \\
\hline & Spring, 2007 & 4 & 40 & 24 & 11 & 21 & 100 \\
\hline \multirow[t]{5}{*}{ Canada } & Spring, 2017 & 2 & 25 & 34 & 25 & 14 & 100 \\
\hline & Spring, 2015 & 3 & 23 & 36 & 23 & 14 & 100 \\
\hline & Spring, 2013 & 3 & 39 & 31 & 8 & 19 & 100 \\
\hline & Spring, 2009 & 5 & 46 & 22 & 8 & 19 & 100 \\
\hline & Spring, 2007 & 7 & 45 & 23 & 7 & 18 & 100 \\
\hline \multirow[t]{9}{*}{ France } & Spring, 2017 & 5 & 31 & 38 & 24 & 2 & 100 \\
\hline & Spring, 2015 & 4 & 26 & 40 & 30 & 0 & 100 \\
\hline & Spring, 2014 & 4 & 22 & 34 & 39 & 1 & 100 \\
\hline & Spring, 2013 & 3 & 33 & 41 & 23 & 0 & 100 \\
\hline & Spring, 2012 & 3 & 33 & 41 & 23 & 0 & 100 \\
\hline & Spring, 2011 & 4 & 49 & 37 & 11 & 0 & 100 \\
\hline & Spring, 2010 & 3 & 48 & 37 & 12 & 0 & 100 \\
\hline & Spring, 2009 & 2 & 41 & 42 & 14 & 1 & 100 \\
\hline & Spring, 2007 & 2 & 33 & 48 & 17 & 0 & 100 \\
\hline \multirow[t]{9}{*}{ Germany } & Spring, 2017 & 4 & 23 & 53 & 14 & 6 & 100 \\
\hline & Spring, 2015 & 3 & 24 & 47 & 23 & 3 & 100 \\
\hline & Spring, 2014 & 1 & 18 & 59 & 20 & 2 & 100 \\
\hline & Spring, 2013 & 1 & 31 & 49 & 11 & 7 & 100 \\
\hline & Spring, 2012 & 3 & 30 & 55 & 9 & 3 & 100 \\
\hline & Spring, 2011 & 2 & 45 & 42 & 7 & 5 & 100 \\
\hline & Spring, 2010 & 3 & 47 & 38 & 7 & 5 & 100 \\
\hline & Spring, 2009 & 2 & 40 & 41 & 10 & 7 & 100 \\
\hline & Spring, 2007 & 2 & 32 & 52 & 10 & 4 & 100 \\
\hline \multirow[t]{4}{*}{ Greece } & Spring, 2017 & 14 & 50 & 23 & 8 & 5 & 100 \\
\hline & Spring, 2014 & 13 & 48 & 24 & 11 & 4 & 100 \\
\hline & Spring, 2013 & 13 & 50 & 23 & 10 & 5 & 100 \\
\hline & Spring, 2012 & 13 & 48 & 22 & 14 & 4 & 100 \\
\hline Hungary & Spring, 2017 & 3 & 36 & 38 & 10 & 13 & 100 \\
\hline \multirow[t]{6}{*}{ I taly } & Spring, 2017 & 5 & 30 & 39 & 15 & 11 & 100 \\
\hline & Spring, 2015 & 4 & 23 & 46 & 23 & 5 & 100 \\
\hline & Spring, 2014 & 2 & 18 & 42 & 32 & 5 & 100 \\
\hline & Spring, 2013 & 4 & 27 & 35 & 21 & 13 & 100 \\
\hline & Spring, 2012 & 2 & 21 & 37 & 30 & 10 & 100 \\
\hline & Spring, 2007 & 2 & 35 & 41 & 8 & 14 & 100 \\
\hline Netherlands & Spring, 2017 & 2 & 13 & 41 & 41 & 4 & 100 \\
\hline \multirow[t]{9}{*}{ Poland } & Spring, 2017 & 2 & 19 & 44 & 25 & 10 & 100 \\
\hline & Spring, 2015 & 2 & 13 & 40 & 40 & 5 & 100 \\
\hline & Spring, 2014 & 2 & 10 & 37 & 44 & 7 & 100 \\
\hline & Spring, 2013 & 3 & 33 & 42 & 12 & 9 & 100 \\
\hline & Spring, 2012 & 3 & 31 & 40 & 20 & 7 & 100 \\
\hline & Spring, 2011 & 3 & 32 & 41 & 12 & 11 & 100 \\
\hline & Spring, 2010 & 6 & 39 & 35 & 11 & 7 & 100 \\
\hline & Spring, 2009 & 2 & 31 & 40 & 16 & 10 & 100 \\
\hline & Spring, 2007 & 4 & 30 & 39 & 19 & 8 & 100 \\
\hline Spain & \begin{tabular}{|l|} 
Spring, 2017 \\
\end{tabular} & 8 & 19 & 35 & 25 & 14 & 100 \\
\hline & Spring, 2015 & 6 & 19 & 41 & 25 & 9 & 100 \\
\hline & Spring, 2014 & 3 & 15 & 48 & 26 & 7 & 100 \\
\hline & \begin{tabular}{|l|} 
Spring, 2013 \\
\end{tabular} & 10 & 28 & 34 & 17 & 12 & 100 \\
\hline & \begin{tabular}{|l|} 
Spring, 2012 \\
\end{tabular} & 9 & 27 & 34 & 20 & 11 & 100 \\
\hline & Spring, 2011 & 10 & 36 & 31 & 14 & 10 & 100 \\
\hline & Spring, 2010 & 4 & 36 & 35 & 9 & 16 & 100 \\
\hline & Spring, 2009 & 3 & 33 & 35 & 9 & 20 & 100 \\
\hline & Spring, 2007 & 3 & 32 & 37 & 12 & 17 & 100 \\
\hline Sweden & Spring, 2017 & 2 & 16 & 49 & 29 & 4 & 100 \\
\hline & Spring, 2007 & 3 & 28 & 48 & 11 & 10 & 100 \\
\hline United Kingdom & Spring, 2017 & 4 & 22 & 35 & 24 & 15 & 100 \\
\hline & \begin{tabular}{|l|} 
Spring, 2015 \\
\end{tabular} & 3 & 15 & 38 & 28 & 16 & 100 \\
\hline & Spring, 2014 & 4 & 21 & 38 & 25 & 12 & 100 \\
\hline & Spring, 2013 & 4 & 34 & 30 & 9 & 23 & 100 \\
\hline & \begin{tabular}{|l|} 
Spring, 2012 \\
\end{tabular} & 3 & 35 & 32 & 11 & 19 & 100 \\
\hline & Spring, 2011 & 7 & 43 & 24 & 7 & 19 & 100 \\
\hline & Spring, 2010 & 6 & 40 & 26 & 6 & 22 & 100 \\
\hline & Spring, 2009 & 5 & 40 & 26 & 7 & 21 & 100 \\
\hline & Spring, 2007 & 4 & 43 & 26 & 5 & 23 & 100 \\
\hline
\end{tabular}




\begin{tabular}{|c|c|c|c|c|c|c|c|}
\hline & & \multicolumn{6}{|c|}{ Q12e. Please tell me if you have a very favorable, somewhat favorable, somewhat unfavorable or very unfavorable opinion of } \\
\hline & & Very favorable & $\begin{array}{l}\text { Somewhat } \\
\text { favorable }\end{array}$ & $\begin{array}{l}\text { Somewhat } \\
\text { unfavorable }\end{array}$ & Very unfavorable & DK/ Refused & Total \\
\hline \multirow[t]{3}{*}{ Australia } & Spring, 2017 & 5 & 32 & 37 & 18 & 7 & 100 \\
\hline & Spring, 2015 & 2 & 22 & 40 & 22 & 13 & 100 \\
\hline & Spring, 2013 & 1 & 41 & 30 & 9 & 19 & 100 \\
\hline \multirow[t]{4}{*}{ India } & Spring, 2017 & 22 & 25 & 8 & 5 & 40 & 100 \\
\hline & Spring, 2015 & 18 & 25 & 12 & 5 & 41 & 100 \\
\hline & Spring, 2014 & 17 & 22 & 10 & 6 & 45 & 100 \\
\hline & Winter, 2013-2014 & 18 & 27 & 13 & 10 & 32 & 100 \\
\hline \multirow[t]{8}{*}{ Indonesia } & Spring, 2017 & 4 & 32 & 32 & 8 & 24 & 100 \\
\hline & Spring, 2015 & 6 & 22 & 29 & 14 & 29 & 100 \\
\hline & Spring, 2014 & 4 & 34 & 36 & 7 & 19 & 100 \\
\hline & Spring, 2013 & 9 & 34 & 25 & 8 & 24 & 100 \\
\hline & Spring, 2011 & 4 & 31 & 31 & 13 & 21 & 100 \\
\hline & Spring, 2010 & 2 & 36 & 35 & 9 & 19 & 100 \\
\hline & Spring, 2009 & 3 & 29 & 33 & 8 & 28 & 100 \\
\hline & Spring, 2007 & 3 & 33 & 36 & 5 & 23 & 100 \\
\hline \multirow[t]{9}{*}{ Japan } & Spring, 2017 & 1 & 25 & 46 & 18 & 10 & 100 \\
\hline & Spring, 2015 & 1 & 20 & 49 & 24 & 7 & 100 \\
\hline & Spring, 2014 & 1 & 22 & 50 & 19 & 7 & 100 \\
\hline & Spring, 2013 & 1 & 26 & 53 & 11 & 10 & 100 \\
\hline & Spring, 2012 & 2 & 20 & 53 & 19 & 6 & 100 \\
\hline & Spring, 2011 & 1 & 27 & 48 & 14 & 10 & 100 \\
\hline & Spring, 2010 & 1 & 29 & 48 & 12 & 10 & 100 \\
\hline & Spring, 2009 & 1 & 22 & 50 & 18 & 9 & 100 \\
\hline & Spring, 2007 & 2 & 20 & 50 & 17 & 11 & 100 \\
\hline \multirow[t]{4}{*}{ Philippines } & Spring, 2017 & 11 & 44 & 17 & 9 & 19 & 100 \\
\hline & Spring, 2015 & 9 & 35 & 29 & 15 & 13 & 100 \\
\hline & Spring, 2014 & 7 & 39 & 29 & 14 & 11 & 100 \\
\hline & Spring, 2013 & 2 & 33 & 36 & 16 & 12 & 100 \\
\hline \multirow[t]{7}{*}{ South Korea } & Spring, 2017 & 0 & 36 & 36 & 5 & 23 & 100 \\
\hline & Spring, 2015 & 1 & 45 & 39 & 4 & 11 & 100 \\
\hline & Spring, 2014 & 1 & 42 & 43 & 5 & 8 & 100 \\
\hline & Spring, 2013 & 3 & 50 & 31 & 2 & 14 & 100 \\
\hline & Spring, 2010 & 1 & 39 & 35 & 10 & 15 & 100 \\
\hline & Spring, 2009 & 1 & 49 & 32 & 3 & 15 & 100 \\
\hline & Spring, 2007 & 2 & 52 & 26 & 4 & 17 & 100 \\
\hline \multirow[t]{3}{*}{ Vietnam } & Spring, 2017 & 37 & 46 & 11 & 2 & 5 & 100 \\
\hline & Spring, 2015 & 36 & 39 & 8 & 2 & 15 & 100 \\
\hline & Spring, 2014 & 38 & 37 & 11 & 3 & 11 & 100 \\
\hline \multirow[t]{7}{*}{ I srael } & Spring, 2017 & 6 & 29 & 44 & 17 & 3 & 100 \\
\hline & Spring, 2015 & 4 & 21 & 51 & 23 & 1 & 100 \\
\hline & Spring, 2014 & 5 & 25 & 46 & 22 & 3 & 100 \\
\hline & Spring, 2013 & 3 & 18 & 47 & 30 & 1 & 100 \\
\hline & Spring, 2011 & 3 & 26 & 38 & 31 & 2 & 100 \\
\hline & Spring, 2009 & 6 & 25 & 38 & 27 & 4 & 100 \\
\hline & Spring, 2007 & 5 & 24 & 41 & 25 & 5 & 100 \\
\hline \multirow[t]{9}{*}{ Jordan } & Spring, 2017 & 1 & 4 & 35 & 58 & 2 & 100 \\
\hline & Spring, 2015 & 3 & 15 & 37 & 43 & 2 & 100 \\
\hline & Spring, 2014 & 3 & 19 & 36 & 39 & 3 & 100 \\
\hline & Spring, 2013 & 4 & 21 & 38 & 32 & 5 & 100 \\
\hline & Spring, 2012 & 4 & 22 & 43 & 27 & 5 & 100 \\
\hline & Spring, 2011 & 5 & 26 & 39 & 24 & 7 & 100 \\
\hline & Spring, 2010 & 6 & 31 & 38 & 20 & 5 & 100 \\
\hline & Spring, 2009 & 8 & 34 & 36 & 22 & 1 & 100 \\
\hline & Spring, 2007 & 10 & 38 & 31 & 18 & 3 & 100 \\
\hline \multirow[t]{9}{*}{ Lebanon } & Spring, 2017 & 20 & 27 & 23 & 25 & 5 & 100 \\
\hline & Spring, 2015 & 23 & 21 & 27 & 29 & 0 & 100 \\
\hline & Spring, 2014 & 23 & 22 & 27 & 27 & 1 & 100 \\
\hline & Spring, 2013 & 18 & 28 & 28 & 25 & 1 & 100 \\
\hline & Spring, 2012 & 16 & 32 & 28 & 20 & 3 & 100 \\
\hline & Spring, 2011 & 14 & 39 & 25 & 18 & 5 & 100 \\
\hline & Spring, 2010 & 12 & 43 & 25 & 15 & 4 & 100 \\
\hline & Spring, 2009 & 13 & 44 & 27 & 11 & 6 & 100 \\
\hline & Spring, 2007 & 13 & 35 & 22 & 25 & 5 & 100 \\
\hline Tunisia & Spring, 2017 & 17 & 22 & 11 & 26 & 24 & 100 \\
\hline & Spring, 2014 & 11 & 24 & 19 & 19 & 27 & 100 \\
\hline & Spring, 2013 & 9 & 26 & 15 & 22 & 29 & 100 \\
\hline & Spring, 2012 & 13 & 27 & 24 & 16 & 20 & 100 \\
\hline
\end{tabular}




\begin{tabular}{|c|c|c|c|c|c|c|c|}
\hline & & \multicolumn{6}{|c|}{ Q12e. Please tell me if you have a very favorable, somewhat favorable, somewhat unfavorable or very unfavorable opinion of } \\
\hline & & Very favorable & $\begin{array}{c}\text { Somewhat } \\
\text { favorable }\end{array}$ & $\begin{array}{l}\text { Somewhat } \\
\text { unfavorable }\end{array}$ & Very unfavorable & DK/ Refused & Total \\
\hline \multirow[t]{9}{*}{ Turkey } & Spring, 2017 & 6 & 26 & 25 & 37 & 6 & 100 \\
\hline & Spring, 2015 & 2 & 13 & 28 & 36 & 20 & 100 \\
\hline & Spring, 2014 & 3 & 13 & 16 & 57 & 11 & 100 \\
\hline & Spring, 2013 & 1 & 18 & 23 & 43 & 15 & 100 \\
\hline & Spring, 2012 & 3 & 13 & 15 & 48 & 20 & 100 \\
\hline & Spring, 2011 & 3 & 15 & 23 & 44 & 16 & 100 \\
\hline & Spring, 2010 & 1 & 15 & 17 & 48 & 18 & 100 \\
\hline & Spring, 2009 & 2 & 11 & 14 & 49 & 24 & 100 \\
\hline & Spring, 2007 & 1 & 16 & 16 & 48 & 18 & 100 \\
\hline \multirow[t]{5}{*}{ Ghana } & Spring, 2017 & 16 & 17 & 7 & 17 & 43 & 100 \\
\hline & Spring, 2015 & 24 & 32 & 17 & 10 & 17 & 100 \\
\hline & Spring, 2014 & 13 & 29 & 17 & 14 & 27 & 100 \\
\hline & \begin{tabular}{|l|} 
Spring, 2013 \\
\end{tabular} & 15 & 34 & 19 & 7 & 26 & 100 \\
\hline & Spring, 2007 & 16 & 39 & 19 & 8 & 18 & 100 \\
\hline \multirow[t]{8}{*}{ Kenya } & Spring, 2017 & 9 & 18 & 14 & 15 & 44 & 100 \\
\hline & Spring, 2015 & 10 & 25 & 26 & 21 & 19 & 100 \\
\hline & Spring, 2014 & 16 & 33 & 24 & 8 & 19 & 100 \\
\hline & Spring, 2013 & 17 & 30 & 20 & 7 & 26 & 100 \\
\hline & Spring, 2011 & 8 & 26 & 26 & 19 & 20 & 100 \\
\hline & Spring, 2010 & 16 & 31 & 31 & 11 & 11 & 100 \\
\hline & Spring, 2009 & 10 & 25 & 21 & 18 & 25 & 100 \\
\hline & Spring, 2007 & 17 & 40 & 26 & 9 & 8 & 100 \\
\hline \multirow[t]{5}{*}{ Nigeria } & Spring, 2017 & 21 & 24 & 14 & 15 & 27 & 100 \\
\hline & Spring, 2015 & 15 & 24 & 21 & 17 & 24 & 100 \\
\hline & Spring, 2014 & 15 & 26 & 12 & 15 & 32 & 100 \\
\hline & Spring, 2013 & 7 & 31 & 15 & 15 & 32 & 100 \\
\hline & Spring, 2010 & 18 & 35 & 19 & 12 & 16 & 100 \\
\hline \multirow[t]{4}{*}{ Senegal } & Spring, 2017 & 5 & 29 & 11 & 7 & 48 & 100 \\
\hline & Spring, 2015 & 11 & 21 & 17 & 15 & 36 & 100 \\
\hline & Spring, 2014 & 14 & 25 & 18 & 12 & 31 & 100 \\
\hline & Spring, 2013 & 17 & 25 & 14 & 7 & 37 & 100 \\
\hline \multirow[t]{4}{*}{ South Africa } & Spring, 2017 & 10 & 18 & 14 & 26 & 32 & 100 \\
\hline & Spring, 2015 & 8 & 17 & 18 & 33 & 24 & 100 \\
\hline & Spring, 2014 & 5 & 20 & 26 & 25 & 24 & 100 \\
\hline & Spring, 2013 & 6 & 20 & 25 & 28 & 20 & 100 \\
\hline \multirow[t]{4}{*}{ Tanzania } & Spring, 2017 & 15 & 30 & 11 & 10 & 34 & 100 \\
\hline & Spring, 2015 & 16 & 22 & 13 & 11 & 39 & 100 \\
\hline & Spring, 2014 & 16 & 33 & 15 & 10 & 26 & 100 \\
\hline & Spring, 2007 & 20 & 30 & 11 & 9 & 30 & 100 \\
\hline Argentina & Spring, 2017 & 7 & 20 & 15 & 12 & 46 & 100 \\
\hline & Spring, 2015 & 4 & 23 & 24 & 13 & 36 & 100 \\
\hline & Spring, 2014 & 3 & 16 & 23 & 14 & 45 & 100 \\
\hline & Spring, 2013 & 3 & 23 & 20 & 9 & 45 & 100 \\
\hline & Spring, 2010 & 2 & 22 & 20 & 14 & 41 & 100 \\
\hline & Spring, 2009 & 3 & 20 & 19 & 9 & 48 & 100 \\
\hline & Spring, 2007 & 1 & 18 & 19 & 15 & 47 & 100 \\
\hline Brazil & Spring, 2017 & 4 & 31 & 31 & 5 & 29 & 100 \\
\hline & Spring, 2015 & 3 & 23 & 37 & 24 & 14 & 100 \\
\hline & Spring, 2014 & 1 & 23 & 48 & 11 & 17 & 100 \\
\hline & Spring, 2013 & 2 & 32 & 41 & 11 & 14 & 100 \\
\hline & Spring, 2012 & 2 & 25 & 34 & 22 & 16 & 100 \\
\hline & Spring, 2011 & 2 & 31 & 33 & 14 & 21 & 100 \\
\hline & Spring, 2010 & 1 & 37 & 34 & 9 & 19 & 100 \\
\hline Chile & \begin{tabular}{|l|} 
Spring, 2017 \\
\end{tabular} & 8 & 26 & 17 & 14 & 34 & 100 \\
\hline & Spring, 2015 & 5 & 26 & 36 & 16 & 17 & 100 \\
\hline & Spring, 2014 & 4 & 30 & 32 & 13 & 21 & 100 \\
\hline & \begin{tabular}{|l|} 
Spring, 2013 \\
\end{tabular} & 5 & 34 & 29 & 9 & 23 & 100 \\
\hline & Spring, 2007 & 8 & 39 & 25 & 4 & 24 & 100 \\
\hline Colombia & Spring, 2017 & 7 & 25 & 17 & 14 & 37 & 100 \\
\hline & Spring, 2014 & 7 & 17 & 16 & 21 & 38 & 100 \\
\hline Mexico & Spring, 2017 & 6 & 26 & 13 & 12 & 43 & 100 \\
\hline & Spring, 2015 & 2 & 22 & 27 & 22 & 27 & 100 \\
\hline & Spring, 2014 & 4 & 17 & 22 & 22 & 36 & 100 \\
\hline & Spring, 2013 & 4 & 24 & 25 & 13 & 35 & 100 \\
\hline & Spring, 2012 & 5 & 20 & 17 & 20 & 37 & 100 \\
\hline & Spring, 2011 & 1 & 22 & 32 & 16 & 29 & 100 \\
\hline & Spring, 2010 & 4 & 21 & 18 & 13 & 45 & 100 \\
\hline & Spring, 2009 & 6 & 23 & 22 & 14 & 36 & 100 \\
\hline & Spring, 2007 & 5 & 33 & 25 & 11 & 26 & 100 \\
\hline Peru & Spring, 2017 & 9 & 32 & 17 & 14 & 28 & 100 \\
\hline & Spring, 2015 & 6 & 27 & 24 & 9 & 34 & 100 \\
\hline & Spring, 2014 & 5 & 29 & 26 & 9 & 30 & 100 \\
\hline & Spring, 2007 & 5 & 32 & 19 & 9 & 35 & 100 \\
\hline
\end{tabular}




\begin{tabular}{|c|c|c|c|c|c|c|c|}
\hline & & \multicolumn{6}{|c|}{ Q12e. Please tell me if you have a very favorable, somewhat favorable, somewhat unfavorable or very unfavorable opinion of } \\
\hline & & Very favorable & $\begin{array}{c}\text { Somewhat } \\
\text { favorable }\end{array}$ & $\begin{array}{l}\text { Somewhat } \\
\text { unfavorable }\end{array}$ & Very unfavorable & DK/ Refused & Total \\
\hline \multirow[t]{4}{*}{ Venezuela } & Spring, 2017 & 11 & 27 & 14 & 19 & 30 & 100 \\
\hline & Spring, 2015 & 8 & 23 & 21 & 30 & 18 & 100 \\
\hline & Spring, 2014 & 11 & 25 & 20 & 31 & 13 & 100 \\
\hline & Spring, 2013 & 14 & 26 & 19 & 22 & 20 & 100 \\
\hline
\end{tabular}

\begin{tabular}{|c|c|c|c|c|c|c|}
\hline & & \multicolumn{5}{|c|}{$\begin{array}{l}\text { Q17c. I'd like your opinion about some possible international concerns for (survey country). Do you think } \\
\text { that } \\
\text { is a major threat, a minor threat or not a threat to (survey country)? c. Russia's power and } \\
\text { influence }\end{array}$} \\
\hline & & Major threat & Minor threat & Not a threat & DK/ Refused & Total \\
\hline United States & Spring, 2017 & 47 & 41 & 9 & 3 & 100 \\
\hline Canada & Spring, 2017 & 30 & 47 & 17 & 7 & 100 \\
\hline France & Spring, 2017 & 45 & 39 & 14 & 2 & 100 \\
\hline Germany & Spring, 2017 & 33 & 53 & 12 & 2 & 100 \\
\hline Greece & Spring, 2017 & 24 & 24 & 50 & 3 & 100 \\
\hline Hungary & Spring, 2017 & 28 & 45 & 22 & 6 & 100 \\
\hline I taly & Spring, 2017 & 31 & 35 & 25 & 9 & 100 \\
\hline Netherlands & Spring, 2017 & 44 & 44 & 10 & 2 & 100 \\
\hline Poland & Spring, 2017 & 65 & 25 & 5 & 5 & 100 \\
\hline Spain & Spring, 2017 & 47 & 28 & 18 & 6 & 100 \\
\hline Sweden & Spring, 2017 & 39 & 52 & 8 & 1 & 100 \\
\hline United Kingdom & Spring, 2017 & 43 & 41 & 10 & 6 & 100 \\
\hline Australia & Spring, 2017 & 29 & 50 & 17 & 4 & 100 \\
\hline India & Spring, 2017 & 17 & 20 & 25 & 38 & 100 \\
\hline Indonesia & Spring, 2017 & 35 & 27 & 19 & 19 & 100 \\
\hline Japan & Spring, 2017 & 43 & 40 & 9 & 8 & 100 \\
\hline Philippines & Spring, 2017 & 26 & 29 & 31 & 14 & 100 \\
\hline South Korea & Spring, 2017 & 46 & 39 & 9 & 6 & 100 \\
\hline Vietnam & Spring, 2017 & 11 & 27 & 54 & 8 & 100 \\
\hline I srael & Spring, 2017 & 27 & 46 & 25 & 2 & 100 \\
\hline Jordan & Spring, 2017 & 49 & 34 & 16 & 2 & 100 \\
\hline Lebanon & Spring, 2017 & 35 & 19 & 43 & 3 & 100 \\
\hline Tunisia & Spring, 2017 & 33 & 17 & 36 & 14 & 100 \\
\hline Turkey & Spring, 2017 & 54 & 25 & 15 & 6 & 100 \\
\hline Ghana & Spring, 2017 & 32 & 18 & 22 & 28 & 100 \\
\hline Kenya & Spring, 2017 & 39 & 18 & 21 & 23 & 100 \\
\hline Nigeria & Spring, 2017 & 29 & 23 & 29 & 19 & 100 \\
\hline Senegal & Spring, 2017 & 16 & 18 & 34 & 32 & 100 \\
\hline South Africa & Spring, 2017 & 33 & 23 & 22 & 23 & 100 \\
\hline Tanzania & Spring, 2017 & 24 & 19 & 36 & 20 & 100 \\
\hline Argentina & Spring, 2017 & 24 & 21 & 30 & 25 & 100 \\
\hline Brazil & Spring, 2017 & 31 & 25 & 27 & 17 & 100 \\
\hline Chile & Spring, 2017 & 30 & 25 & 28 & 18 & 100 \\
\hline Colombia & Spring, 2017 & 19 & 26 & 35 & 20 & 100 \\
\hline Mexico & Spring, 2017 & 23 & 30 & 26 & 21 & 100 \\
\hline Peru & Spring, 2017 & 19 & 26 & 39 & 16 & 100 \\
\hline Venezuela & Spring, 2017 & 19 & 20 & 45 & 16 & 100 \\
\hline
\end{tabular}




\begin{tabular}{|c|c|c|c|c|c|}
\hline & & \multicolumn{4}{|c|}{$\begin{array}{l}\text { Q27d. Do you think the government of }- \text { respects the personal freedoms of its } \\
\text { people or don't you think so? d. Russia }\end{array}$} \\
\hline & & $\begin{array}{l}\text { Yes, respects } \\
\text { personal freedoms }\end{array}$ & $\begin{array}{l}\text { No, does not } \\
\text { respect personal } \\
\text { freedoms }\end{array}$ & DK/ Refused & Total \\
\hline \multirow[t]{3}{*}{ United States } & Spring, 2017 & 14 & 80 & 6 & 100 \\
\hline & Spring, 2014 & 10 & 81 & 8 & 100 \\
\hline & Spring, 2008 & 23 & 59 & 19 & 100 \\
\hline Canada & Spring, 2017 & 15 & 73 & 12 & 100 \\
\hline \multirow[t]{3}{*}{ France } & Spring, 2017 & 14 & 84 & 2 & 100 \\
\hline & Spring, 2014 & 13 & 86 & 1 & 100 \\
\hline & Spring, 2008 & 14 & 86 & 0 & 100 \\
\hline \multirow[t]{3}{*}{ Germany } & Spring, 2017 & 14 & 82 & 4 & 100 \\
\hline & Spring, 2014 & 8 & 89 & 3 & 100 \\
\hline & Spring, 2008 & 16 & 80 & 5 & 100 \\
\hline \multirow[t]{2}{*}{ Greece } & Spring, 2017 & 43 & 47 & 10 & 100 \\
\hline & Spring, 2014 & 40 & 53 & 7 & 100 \\
\hline Hungary & Spring, 2017 & 28 & 55 & 17 & 100 \\
\hline \multirow[t]{2}{*}{ I taly } & Spring, 2017 & 19 & 68 & 13 & 100 \\
\hline & Spring, 2014 & 15 & 72 & 13 & 100 \\
\hline Netherlands & Spring, 2017 & 10 & 87 & 2 & 100 \\
\hline \multirow[t]{3}{*}{ Poland } & Spring, 2017 & 8 & 82 & 10 & 100 \\
\hline & Spring, 2014 & 11 & 80 & 9 & 100 \\
\hline & Spring, 2008 & 12 & 79 & 9 & 100 \\
\hline \multirow[t]{3}{*}{ Spain } & Spring, 2017 & 16 & 70 & 14 & 100 \\
\hline & Spring, 2014 & 11 & 80 & 9 & 100 \\
\hline & Spring, 2008 & 17 & 64 & 18 & 100 \\
\hline Sweden & Spring, 2017 & 6 & 91 & 3 & 100 \\
\hline \multirow[t]{3}{*}{ United Kingdom } & Spring, 2017 & 14 & 73 & 13 & 100 \\
\hline & Spring, 2014 & 12 & 76 & 12 & 100 \\
\hline & Spring, 2008 & 18 & 64 & 18 & 100 \\
\hline \multirow[t]{2}{*}{ Australia } & Spring, 2017 & 14 & 75 & 11 & 100 \\
\hline & Spring, 2008 & 24 & 57 & 19 & 100 \\
\hline \multirow[t]{2}{*}{ India } & Spring, 2017 & 36 & 13 & 51 & 100 \\
\hline & Spring, 2014 & 30 & 15 & 55 & 100 \\
\hline \multirow[t]{3}{*}{ I ndonesia } & Spring, 2017 & 41 & 29 & 30 & 100 \\
\hline & Spring, 2014 & 35 & 36 & 29 & 100 \\
\hline & Spring, 2008 & 32 & 31 & 38 & 100 \\
\hline \multirow[t]{3}{*}{ Japan } & Spring, 2017 & 23 & 61 & 16 & 100 \\
\hline & Spring, 2014 & 16 & 70 & 14 & 100 \\
\hline & Spring, 2008 & 22 & 63 & 15 & 100 \\
\hline \multirow[t]{2}{*}{ Philippines } & Spring, 2017 & 59 & 21 & 20 & 100 \\
\hline & Spring, 2014 & 49 & 26 & 25 & 100 \\
\hline \multirow[t]{3}{*}{ South Korea } & Spring, 2017 & 28 & 56 & 17 & 100 \\
\hline & Spring, 2014 & 32 & 55 & 12 & 100 \\
\hline & Spring, 2008 & 28 & 52 & 20 & 100 \\
\hline \multirow[t]{2}{*}{ Vietnam } & Spring, 2017 & 85 & 4 & 11 & 100 \\
\hline & Spring, 2014 & 76 & 7 & 16 & 100 \\
\hline \multirow[t]{2}{*}{ I srael } & Spring, 2017 & 25 & 66 & 9 & 100 \\
\hline & Spring, 2014 & 28 & 59 & 13 & 100 \\
\hline \multirow[t]{3}{*}{ J ordan } & Spring, 2017 & 42 & 47 & 10 & 100 \\
\hline & Spring, 2014 & 47 & 40 & 13 & 100 \\
\hline & Spring, 2008 & 27 & 60 & 13 & 100 \\
\hline \multirow[t]{3}{*}{ Lebanon } & Spring, 2017 & 70 & 25 & 5 & 100 \\
\hline & Spring, 2014 & 51 & 41 & 8 & 100 \\
\hline & Spring, 2008 & 38 & 52 & 10 & 100 \\
\hline Tunisia & Spring, 2017 & 80 & 14 & 6 & 100 \\
\hline & Spring, 2014 & 46 & 26 & 27 & 100 \\
\hline
\end{tabular}




\begin{tabular}{|c|c|c|c|c|c|}
\hline & & \multicolumn{4}{|c|}{$\begin{array}{l}\text { Q27d. Do you think the government of - respects the personal freedoms of its } \\
\text { people or don't you think so? d. Russia }\end{array}$} \\
\hline & & $\begin{array}{l}\text { Yes, respects } \\
\text { personal freedoms }\end{array}$ & $\begin{array}{l}\text { No, does not } \\
\text { respect personal } \\
\text { freedoms }\end{array}$ & DK/ Refused & Total \\
\hline \multirow[t]{3}{*}{ Turkey } & Spring, 2017 & 39 & 36 & 24 & 100 \\
\hline & Spring, 2014 & 38 & 40 & 22 & 100 \\
\hline & Spring, 2008 & 37 & 27 & 36 & 100 \\
\hline \multirow[t]{2}{*}{ Ghana } & Spring, 2017 & 49 & 14 & 37 & 100 \\
\hline & Spring, 2014 & 49 & 18 & 34 & 100 \\
\hline \multirow[t]{2}{*}{ Kenya } & Spring, 2017 & 53 & 20 & 27 & 100 \\
\hline & Spring, 2014 & 49 & 24 & 28 & 100 \\
\hline \multirow[t]{2}{*}{ Nigeria } & Spring, 2017 & 65 & 13 & 22 & 100 \\
\hline & Spring, 2014 & 34 & 15 & 51 & 100 \\
\hline \multirow[t]{2}{*}{ Senegal } & Spring, 2017 & 65 & 17 & 18 & 100 \\
\hline & Spring, 2014 & 26 & 21 & 53 & 100 \\
\hline \multirow[t]{3}{*}{ South Africa } & Spring, 2017 & 45 & 25 & 31 & 100 \\
\hline & Spring, 2014 & 21 & 35 & 44 & 100 \\
\hline & Spring, 2008 & 28 & 25 & 48 & 100 \\
\hline \multirow[t]{3}{*}{ Tanzania } & Spring, 2017 & 45 & 28 & 26 & 100 \\
\hline & Spring, 2014 & 37 & 27 & 36 & 100 \\
\hline & Spring, 2008 & 50 & 22 & 28 & 100 \\
\hline \multirow[t]{3}{*}{ Argentina } & Spring, 2017 & 23 & 34 & 43 & 100 \\
\hline & Spring, 2014 & 14 & 32 & 54 & 100 \\
\hline & Spring, 2008 & 22 & 31 & 46 & 100 \\
\hline \multirow[t]{2}{*}{ Brazil } & Spring, 2017 & 29 & 48 & 23 & 100 \\
\hline & Spring, 2014 & 23 & 57 & 20 & 100 \\
\hline \multirow[t]{2}{*}{ Chile } & Spring, 2017 & 30 & 46 & 24 & 100 \\
\hline & Spring, 2014 & 16 & 49 & 35 & 100 \\
\hline \multirow[t]{2}{*}{ Colombia } & Spring, 2017 & 25 & 39 & 35 & 100 \\
\hline & Spring, 2014 & 14 & 37 & 49 & 100 \\
\hline \multirow[t]{3}{*}{ Mexico } & Spring, 2017 & 33 & 38 & 29 & 100 \\
\hline & Spring, 2014 & 18 & 38 & 44 & 100 \\
\hline & Spring, 2008 & 28 & 38 & 34 & 100 \\
\hline \multirow[t]{2}{*}{ Peru } & Spring, 2017 & 31 & 42 & 26 & 100 \\
\hline & Spring, 2014 & 22 & 39 & 40 & 100 \\
\hline \multirow[t]{2}{*}{ Venezuela } & Spring, 2017 & 39 & 33 & 28 & 100 \\
\hline & Spring, 2014 & 28 & 40 & 32 & 100 \\
\hline
\end{tabular}




\begin{tabular}{|c|c|c|c|c|c|c|c|}
\hline & & \multicolumn{6}{|c|}{$\begin{array}{l}\text { Q30c. For each, tell me how much confidence you have in each leader to do the right thing regarding world affairs - a lot of } \\
\text { confidence, some confidence, not too much confidence or no confidence at all. c. Russian President Vladimir Putin }\end{array}$} \\
\hline & & A lot of confidence & Some confidence & $\begin{array}{l}\text { Not too much } \\
\text { confidence }\end{array}$ & $\begin{array}{l}\text { No confidence at } \\
\text { all }\end{array}$ & DK/ Refused & Total \\
\hline \multirow[t]{8}{*}{ United States } & Spring, 2017 & 2 & 21 & 26 & 48 & 3 & 100 \\
\hline & Spring, 2015 & 2 & 19 & 26 & 49 & 5 & 100 \\
\hline & Spring, 2014 & 3 & 13 & 27 & 53 & 5 & 100 \\
\hline & Spring, 2012 & 4 & 24 & 29 & 25 & 18 & 100 \\
\hline & Spring, 2008 & 2 & 26 & 22 & 26 & 25 & 100 \\
\hline & Spring, 2007 & 2 & 28 & 25 & 25 & 21 & 100 \\
\hline & Spring, 2006 & 3 & 30 & 26 & 19 & 22 & 100 \\
\hline & May, 2003 & 2 & 39 & 28 & 19 & 13 & 100 \\
\hline \multirow[t]{5}{*}{ Canada } & Spring, 2017 & 3 & 16 & 25 & 49 & 7 & 100 \\
\hline & Spring, 2016 & 6 & 20 & 20 & 45 & 10 & 100 \\
\hline & Spring, 2015 & 2 & 15 & 31 & 45 & 6 & 100 \\
\hline & Spring, 2007 & 4 & 32 & 26 & 22 & 17 & 100 \\
\hline & May, 2003 & 6 & 48 & 21 & 13 & 13 & 100 \\
\hline \multirow[t]{10}{*}{ France } & Spring, 2017 & 2 & 16 & 28 & 52 & 1 & 100 \\
\hline & Spring, 2016 & 4 & 16 & 30 & 48 & 2 & 100 \\
\hline & Spring, 2015 & 3 & 12 & 29 & 56 & 0 & 100 \\
\hline & Spring, 2014 & 4 & 12 & 26 & 59 & 0 & 100 \\
\hline & Spring, 2012 & 2 & 10 & 31 & 57 & 0 & 100 \\
\hline & Spring, 2008 & 1 & 16 & 30 & 52 & 1 & 100 \\
\hline & Spring, 2007 & 2 & 17 & 36 & 45 & 0 & 100 \\
\hline & Spring, 2006 & 2 & 22 & 33 & 43 & 1 & 100 \\
\hline & May, 2003 & 5 & 43 & 27 & 25 & 1 & 100 \\
\hline & August, 2001 & 2 & 12 & 39 & 38 & 9 & 100 \\
\hline \multirow[t]{10}{*}{ Germany } & Spring, 2017 & 5 & 20 & 39 & 35 & 1 & 100 \\
\hline & Spring, 2016 & 6 & 25 & 36 & 32 & 1 & 100 \\
\hline & Spring, 2015 & 5 & 18 & 36 & 40 & 2 & 100 \\
\hline & Spring, 2014 & 3 & 19 & 33 & 44 & 1 & 100 \\
\hline & Spring, 2012 & 4 & 18 & 39 & 38 & 2 & 100 \\
\hline & Spring, 2008 & 7 & 31 & 31 & 29 & 2 & 100 \\
\hline & Spring, 2007 & 5 & 27 & 37 & 29 & 2 & 100 \\
\hline & Spring, 2006 & 5 & 45 & 29 & 17 & 4 & 100 \\
\hline & May, 2003 & 24 & 51 & 18 & 6 & 1 & 100 \\
\hline & August, 2001 & 4 & 37 & 31 & 24 & 4 & 100 \\
\hline \multirow[t]{4}{*}{ Greece } & Spring, 2017 & 13 & 37 & 27 & 18 & 5 & 100 \\
\hline & Spring, 2016 & 15 & 38 & 26 & 18 & 3 & 100 \\
\hline & Spring, 2014 & 9 & 32 & 31 & 26 & 2 & 100 \\
\hline & Spring, 2012 & 7 & 32 & 29 & 29 & 3 & 100 \\
\hline \multirow[t]{2}{*}{ Hungary } & Spring, 2017 & 4 & 30 & 33 & 24 & 9 & 100 \\
\hline & Spring, 2016 & 6 & 32 & 33 & 19 & 10 & 100 \\
\hline \multirow[t]{8}{*}{ I taly } & Spring, 2017 & 3 & 23 & 37 & 27 & 10 & 100 \\
\hline & Spring, 2016 & 9 & 22 & 34 & 24 & 11 & 100 \\
\hline & Spring, 2015 & 2 & 16 & 43 & 34 & 5 & 100 \\
\hline & Spring, 2014 & 2 & 16 & 40 & 38 & 4 & 100 \\
\hline & Spring, 2012 & 2 & 15 & 38 & 35 & 10 & 100 \\
\hline & Spring, 2007 & 2 & 24 & 36 & 24 & 14 & 100 \\
\hline & May, 2003 & 5 & 39 & 35 & 12 & 8 & 100 \\
\hline & August, 2001 & 3 & 21 & 36 & 13 & 28 & 100 \\
\hline \multirow[t]{2}{*}{ Netherlands } & Spring, 2017 & 2 & 10 & 28 & 59 & 1 & 100 \\
\hline & Spring, 2016 & 1 & 12 & 27 & 58 & 2 & 100 \\
\hline \multirow[t]{7}{*}{ Poland } & Spring, 2017 & 0 & 4 & 27 & 62 & 7 & 100 \\
\hline & Spring, 2016 & 1 & 6 & 26 & 60 & 7 & 100 \\
\hline & Spring, 2015 & 1 & 8 & 26 & 61 & 3 & 100 \\
\hline & Spring, 2014 & 1 & 7 & 29 & 57 & 4 & 100 \\
\hline & Spring, 2012 & 3 & 16 & 37 & 37 & 8 & 100 \\
\hline & Spring, 2008 & 1 & 13 & 38 & 40 & 7 & 100 \\
\hline & Spring, 2007 & 0 & 7 & 37 & 44 & 12 & 100 \\
\hline Spain & Spring, 2017 & 0 & 8 & 38 & 50 & 3 & 100 \\
\hline & Spring, 2016 & 2 & 6 & 35 & 53 & 5 & 100 \\
\hline & Spring, 2015 & 1 & 5 & 44 & 48 & 3 & 100 \\
\hline & Spring, 2014 & 1 & 6 & 29 & 58 & 5 & 100 \\
\hline & Spring, 2012 & 2 & 8 & 42 & 45 & 4 & 100 \\
\hline & Spring, 2008 & 1 & 9 & 32 & 48 & 11 & 100 \\
\hline & Spring, 2007 & 2 & 5 & 33 & 43 & 17 & 100 \\
\hline & Spring, 2006 & 1 & 9 & 31 & 46 & 13 & 100 \\
\hline & May, 2003 & 5 & 26 & 24 & 33 & 13 & 100 \\
\hline Sweden & Spring, 2017 & 1 & 11 & 29 & 58 & 1 & 100 \\
\hline & Spring, 2016 & 2 & 10 & 23 & 64 & 1 & 100 \\
\hline & Spring, 2007 & 1 & 22 & 37 & 31 & 9 & 100 \\
\hline
\end{tabular}




\begin{tabular}{|c|c|c|c|c|c|c|c|}
\hline & & \multicolumn{6}{|c|}{$\begin{array}{l}\text { Q30c. For each, tell me how much confidence you have in each leader to do the right thing regarding world affairs - a lot of } \\
\text { confidence, some confidence, not too much confidence or no confidence at all. c. Russian President Vladimir Putin }\end{array}$} \\
\hline & & A lot of confidence & Some confidence & $\begin{array}{l}\text { Not too much } \\
\text { confidence }\end{array}$ & $\begin{array}{l}\text { No confidence at } \\
\text { all }\end{array}$ & DK/ Refused & Total \\
\hline \multirow[t]{10}{*}{ United Kingdom } & Spring, 2017 & 4 & 15 & 29 & 47 & 6 & 100 \\
\hline & Spring, 2016 & 3 & 17 & 26 & 46 & 7 & 100 \\
\hline & Spring, 2015 & 2 & 12 & 27 & 53 & 6 & 100 \\
\hline & Spring, 2014 & 5 & 15 & 32 & 40 & 7 & 100 \\
\hline & Spring, 2012 & 3 & 18 & 34 & 36 & 9 & 100 \\
\hline & Spring, 2008 & 3 & 25 & 24 & 32 & 16 & 100 \\
\hline & Spring, 2007 & 3 & 34 & 26 & 21 & 16 & 100 \\
\hline & Spring, 2006 & 3 & 30 & 27 & 24 & 16 & 100 \\
\hline & May, 2003 & 10 & 43 & 23 & 13 & 10 & 100 \\
\hline & August, 2001 & 1 & 25 & 35 & 22 & 17 & 100 \\
\hline \multirow[t]{5}{*}{ Australia } & Spring, 2017 & 5 & 22 & 31 & 39 & 3 & 100 \\
\hline & Spring, 2016 & 4 & 21 & 25 & 45 & 5 & 100 \\
\hline & Spring, 2015 & 2 & 13 & 33 & 48 & 4 & 100 \\
\hline & Spring, 2008 & 2 & 36 & 26 & 18 & 18 & 100 \\
\hline & May, 2003 & 5 & 48 & 25 & 12 & 11 & 100 \\
\hline \multirow[t]{4}{*}{ India } & Spring, 2017 & 13 & 16 & 9 & 4 & 57 & 100 \\
\hline & Spring, 2016 & 10 & 14 & 9 & 6 & 62 & 100 \\
\hline & Spring, 2015 & 14 & 22 & 8 & 7 & 49 & 100 \\
\hline & Spring, 2014 & 9 & 15 & 10 & 6 & 60 & 100 \\
\hline \multirow[t]{6}{*}{ I ndonesia } & Spring, 2017 & 2 & 29 & 22 & 8 & 38 & 100 \\
\hline & Spring, 2015 & 3 & 22 & 22 & 11 & 42 & 100 \\
\hline & Spring, 2014 & 5 & 23 & 35 & 9 & 28 & 100 \\
\hline & Spring, 2008 & 1 & 17 & 25 & 12 & 45 & 100 \\
\hline & Spring, 2007 & 1 & 21 & 37 & 10 & 31 & 100 \\
\hline & Spring, 2006 & 2 & 19 & 29 & 11 & 38 & 100 \\
\hline \multirow[t]{8}{*}{ Japan } & Spring, 2017 & 2 & 26 & 47 & 17 & 7 & 100 \\
\hline & \begin{tabular}{|l|} 
Spring, 2016 \\
\end{tabular} & 4 & 22 & 43 & 22 & 9 & 100 \\
\hline & Spring, 2015 & 1 & 21 & 47 & 24 & 7 & 100 \\
\hline & Spring, 2014 & 1 & 19 & 52 & 20 & 7 & 100 \\
\hline & \begin{tabular}{|l|} 
Spring, 2012 \\
\end{tabular} & 2 & 25 & 47 & 21 & 6 & 100 \\
\hline & Spring, 2008 & 3 & 25 & 41 & 21 & 10 & 100 \\
\hline & Spring, 2007 & 1 & 18 & 46 & 22 & 14 & 100 \\
\hline & Spring, 2006 & 2 & 38 & 44 & 11 & 5 & 100 \\
\hline \multirow[t]{3}{*}{ Philippines } & Spring, 2017 & 13 & 41 & 13 & 11 & 22 & 100 \\
\hline & Spring, 2015 & 13 & 33 & 23 & 9 & 22 & 100 \\
\hline & Spring, 2014 & 6 & 32 & 24 & 13 & 26 & 100 \\
\hline \multirow[t]{6}{*}{ South Korea } & Spring, 2017 & 2 & 25 & 48 & 14 & 11 & 100 \\
\hline & Spring, 2015 & 2 & 25 & 47 & 19 & 6 & 100 \\
\hline & Spring, 2014 & 3 & 29 & 47 & 13 & 7 & 100 \\
\hline & Spring, 2008 & 1 & 26 & 40 & 6 & 26 & 100 \\
\hline & Spring, 2007 & 0 & 24 & 44 & 7 & 25 & 100 \\
\hline & May, 2003 & 3 & 34 & 39 & 8 & 16 & 100 \\
\hline Vietnam & Spring, 2017 & 35 & 44 & 8 & 1 & 12 & 100 \\
\hline & \begin{tabular}{|l|} 
Spring, 2015 \\
\end{tabular} & 33 & 37 & 9 & 2 & 19 & 100 \\
\hline & Spring, 2014 & 33 & 36 & 7 & 2 & 21 & 100 \\
\hline I srael & Spring, 2017 & 5 & 23 & 42 & 27 & 3 & 100 \\
\hline & Spring, 2015 & 4 & 20 & 41 & 33 & 3 & 100 \\
\hline & Spring, 2014 & 7 & 21 & 37 & 34 & 1 & 100 \\
\hline & Spring, 2007 & 2 & 15 & 34 & 41 & 8 & 100 \\
\hline & May, 2003 & 10 & 27 & 27 & 28 & 8 & 100 \\
\hline Jordan & Spring, 2017 & 1 & 1 & 34 & 58 & 6 & 100 \\
\hline & Spring, 2015 & 1 & 11 & 37 & 44 & 7 & 100 \\
\hline & Spring, 2014 & 1 & 12 & 38 & 41 & 7 & 100 \\
\hline & Spring, 2012 & 2 & 15 & 37 & 35 & 12 & 100 \\
\hline & Spring, 2008 & 1 & 16 & 36 & 36 & 11 & 100 \\
\hline & Spring, 2007 & 1 & 19 & 32 & 32 & 17 & 100 \\
\hline & Spring, 2006 & 2 & 12 & 45 & 33 & 8 & 100 \\
\hline Lebanon & Spring, 2017 & 26 & 20 & 16 & 37 & 2 & 100 \\
\hline & Spring, 2015 & 24 & 18 & 16 & 42 & 0 & 100 \\
\hline & Spring, 2014 & 25 & 17 & 17 & 39 & 2 & 100 \\
\hline & \begin{tabular}{|l|} 
Spring, 2012 \\
\end{tabular} & 6 & 27 & 28 & 35 & 4 & 100 \\
\hline & Spring, 2008 & 7 & 30 & 27 & 32 & 4 & 100 \\
\hline & Spring, 2007 & 7 & 26 & 28 & 33 & 6 & 100 \\
\hline Tunisia & Spring, 2017 & 14 & 18 & 5 & 34 & 29 & 100 \\
\hline & Spring, 2014 & 6 & 15 & 14 & 34 & 31 & 100 \\
\hline & Spring, 2012 & 3 & 14 & 16 & 35 & 32 & 100 \\
\hline Turkey & Spring, 2017 & 4 & 16 & 25 & 49 & 6 & 100 \\
\hline & Spring, 2015 & 6 & 23 & 33 & 27 & 12 & 100 \\
\hline & Spring, 2014 & 4 & 7 & 19 & 56 & 14 & 100 \\
\hline & Spring, 2012 & 3 & 11 & 15 & 55 & 15 & 100 \\
\hline & Spring, 2008 & 2 & 7 & 8 & 62 & 21 & 100 \\
\hline & Spring, 2007 & 1 & 9 & 11 & 60 & 20 & 100 \\
\hline & Spring, 2006 & 1 & 8 & 6 & 62 & 22 & 100 \\
\hline
\end{tabular}




\begin{tabular}{|c|c|c|c|c|c|c|c|}
\hline & & \multicolumn{6}{|c|}{$\begin{array}{l}\text { Q30c. For each, tell me how much confidence you have in each leader to do the right thing regarding world affairs - a lot of } \\
\text { confidence, some confidence, not too much confidence or no confidence at all. c. Russian President Vladimir Putin }\end{array}$} \\
\hline & & A lot of confidence & Some confidence & $\begin{array}{l}\text { Not too much } \\
\text { confidence }\end{array}$ & $\begin{array}{l}\text { No confidence at } \\
\text { all }\end{array}$ & DK/ Refused & Total \\
\hline \multirow[t]{4}{*}{ Ghana } & \begin{tabular}{|l|} 
Spring, 2017 \\
\end{tabular} & 18 & 18 & 9 & 13 & 42 & 100 \\
\hline & Spring, 2015 & 21 & 28 & 18 & 11 & 22 & 100 \\
\hline & Spring, 2014 & 11 & 26 & 12 & 12 & 39 & 100 \\
\hline & Spring, 2007 & 14 & 37 & 20 & 7 & 22 & 100 \\
\hline \multirow[t]{5}{*}{ Kenya } & Spring, 2017 & 8 & 25 & 17 & 25 & 25 & 100 \\
\hline & Spring, 2016 & 6 & 21 & 12 & 24 & 38 & 100 \\
\hline & \begin{tabular}{|l|} 
Spring, 2015 \\
\end{tabular} & 10 & 27 & 24 & 21 & 18 & 100 \\
\hline & Spring, 2014 & 21 & 29 & 17 & 11 & 22 & 100 \\
\hline & Spring, 2007 & 11 & 39 & 27 & 9 & 14 & 100 \\
\hline \multirow[t]{4}{*}{ Nigeria } & Spring, 2017 & 18 & 21 & 16 & 17 & 28 & 100 \\
\hline & Spring, 2016 & 11 & 17 & 12 & 16 & 44 & 100 \\
\hline & Spring, 2015 & 16 & 28 & 20 & 10 & 26 & 100 \\
\hline & Spring, 2014 & 8 & 22 & 14 & 16 & 40 & 100 \\
\hline \multirow[t]{3}{*}{ Senegal } & Spring, 2017 & 13 & 21 & 10 & 16 & 41 & 100 \\
\hline & Spring, 2015 & 6 & 13 & 19 & 19 & 43 & 100 \\
\hline & Spring, 2014 & 7 & 16 & 19 & 17 & 41 & 100 \\
\hline \multirow[t]{5}{*}{ South Africa } & Spring, 2017 & 13 & 20 & 13 & 23 & 31 & 100 \\
\hline & Spring, 2016 & 13 & 20 & 10 & 20 & 37 & 100 \\
\hline & Spring, 2015 & 9 & 19 & 19 & 22 & 31 & 100 \\
\hline & Spring, 2014 & 6 & 17 & 19 & 19 & 38 & 100 \\
\hline & Spring, 2008 & 3 & 13 & 12 & 15 & 57 & 100 \\
\hline \multirow[t]{5}{*}{ Tanzania } & Spring, 2017 & 14 & 37 & 18 & 12 & 18 & 100 \\
\hline & Spring, 2015 & 16 & 22 & 17 & 9 & 37 & 100 \\
\hline & \begin{tabular}{|l|} 
Spring, 2014 \\
\end{tabular} & 16 & 36 & 21 & 6 & 21 & 100 \\
\hline & \begin{tabular}{|l|} 
Spring, 2008 \\
\end{tabular} & 14 & 27 & 15 & 9 & 35 & 100 \\
\hline & Spring, 2007 & 13 & 29 & 13 & 13 & 32 & 100 \\
\hline \multirow[t]{5}{*}{ Argentina } & Spring, 2017 & 5 & 14 & 23 & 28 & 31 & 100 \\
\hline & \begin{tabular}{|l|} 
Spring, 2015 \\
\end{tabular} & 5 & 15 & 25 & 32 & 24 & 100 \\
\hline & Spring, 2014 & 1 & 9 & 20 & 29 & 41 & 100 \\
\hline & Spring, 2008 & 1 & 6 & 13 & 38 & 43 & 100 \\
\hline & Spring, 2007 & 0 & 5 & 13 & 31 & 51 & 100 \\
\hline \multirow[t]{4}{*}{ Brazil } & Spring, 2017 & 4 & 15 & 14 & 46 & 21 & 100 \\
\hline & Spring, 2015 & 4 & 19 & 30 & 36 & 12 & 100 \\
\hline & Spring, 2014 & 1 & 11 & 37 & 32 & 18 & 100 \\
\hline & Spring, 2012 & 2 & 17 & 28 & 28 & 25 & 100 \\
\hline \multirow[t]{4}{*}{ Chile } & Spring, 2017 & 7 & 13 & 25 & 33 & 22 & 100 \\
\hline & Spring, 2015 & 3 & 22 & 30 & 27 & 18 & 100 \\
\hline & Spring, 2014 & 2 & 16 & 31 & 23 & 28 & 100 \\
\hline & Spring, 2007 & 3 & 17 & 26 & 21 & 33 & 100 \\
\hline \multirow[t]{2}{*}{ Colombia } & Spring, 2017 & 5 & 18 & 25 & 30 & 23 & 100 \\
\hline & Spring, 2014 & 4 & 10 & 20 & 21 & 46 & 100 \\
\hline \multirow[t]{6}{*}{ Mexico } & Spring, 2017 & 3 & 16 & 20 & 39 & 21 & 100 \\
\hline & Spring, 2015 & 4 & 15 & 28 & 30 & 23 & 100 \\
\hline & \begin{tabular}{|l|} 
Spring, 2014 \\
\end{tabular} & 2 & 11 & 19 & 34 & 34 & 100 \\
\hline & \begin{tabular}{|l|} 
Spring, 2012 \\
\end{tabular} & 2 & 14 & 22 & 23 & 39 & 100 \\
\hline & Spring, 2008 & 3 & 7 & 21 & 31 & 39 & 100 \\
\hline & Spring, 2007 & 5 & 18 & 21 & 27 & 29 & 100 \\
\hline \multirow[t]{4}{*}{ Peru } & Spring, 2017 & 5 & 19 & 28 & 33 & 15 & 100 \\
\hline & Spring, 2015 & 2 & 15 & 30 & 22 & 30 & 100 \\
\hline & \begin{tabular}{|l|} 
Spring, 2014 \\
\end{tabular} & 2 & 15 & 22 & 21 & 39 & 100 \\
\hline & Spring, 2007 & 1 & 15 & 22 & 24 & 38 & 100 \\
\hline \multirow[t]{3}{*}{ Venezuela } & Spring, 2017 & 9 & 13 & 23 & 42 & 13 & 100 \\
\hline & Spring, 2015 & 4 & 10 & 26 & 44 & 16 & 100 \\
\hline & Spring, 2014 & 4 & 13 & 27 & 43 & 13 & 100 \\
\hline
\end{tabular}

